\title{
Significance of Inducible Defense-related Proteins in Infected Plants
}

\section{L.C. van Loon, ${ }^{1}$ M. Rep, ${ }^{2}$ and C.M.J. Pieterse ${ }^{1}$}

\author{
${ }^{1}$ Phytopathology, Institute of Environmental Biology, Science Faculty, Utrecht \\ University, 3508 TB Utrecht, The Netherlands; email: L.C.Vanloon@bio.uu.nl, \\ C.M.J.Pieterse@bio.uu.nl \\ ${ }^{2}$ Plant Pathology, Swammerdam Institute for Life Sciences, Faculty of Science, \\ University of Amsterdam, 1090 GB Amsterdam, The Netherlands; \\ email: M.Rep@uva.nl
}

Annu. Rev. Phytopathol.

2006. 44:135-62

First published online as a

Review in Advance on

March 3, 2006

The Annual Review of Phytopathology is online at phyto.annualreviews.org

doi: 10.1146/

annurev.phyto.44.070505.143425

Copyright (c) 2006 by

Annual Reviews. All rights reserved

0066-4286/06/0908$0135 \$ 20.00$

\section{Key Words}

antimicrobial activity, defense signaling, developmental regulation, pathogenesis-related proteins, resistance, stress alleviation

\begin{abstract}
Inducible defense-related proteins have been described in many plant species upon infection with oomycetes, fungi, bacteria, or viruses, or insect attack. Several types of proteins are common and have been classified into 17 families of pathogenesis-related proteins (PRs). Others have so far been found to occur more specifically in some plant species. Most PRs and related proteins are induced through the action of the signaling compounds salicylic acid, jasmonic acid, or ethylene, and possess antimicrobial activities in vitro through hydrolytic activities on cell walls, contact toxicity, and perhaps an involvement in defense signaling. However, when expressed in transgenic plants, they reduce only a limited number of diseases, depending on the nature of the protein, plant species, and pathogen involved. As exemplified by the PR-1 proteins in Arabidopsis and rice, many homologous proteins belonging to the same family are regulated developmentally and may serve different functions in specific organs or tissues. Several defense-related proteins are induced during senescence, wounding or cold stress, and some possess antifreeze activity. Many defense-related proteins are present constitutively in floral tissues and a substantial number of PR-like proteins in pollen, fruits, and vegetables can provoke allergy in humans. The evolutionary conservation of similar defense-related proteins in monocots and dicots, but also their divergent occurrence in other conditions, suggest that these proteins serve essential functions in plant life, whether in defense or not.
\end{abstract}




\section{INTRODUCTION}

Plants possess both preformed and inSA: salicylic acid

JA: jasmonic acid

ET: ethylene

$R$ : resistance gene

PR:

pathogenesis-related

SAR: systemic acquired resistance

ducible mechanisms to resist pathogen invasion. Extant morphological barriers, secondary metabolites (phytoanticipins), and antimicrobial proteins must be avoided or overcome for pathogens to be able to invade a plant. Once contact has been established, elicitors produced and released by the pathogen induce further defenses, comprising the reinforcement of cell walls, the production of phytoalexins, and the synthesis of defense-related proteins (133). In the past few years, plant microarray data have been collected showing that in both compatible and incompatible plant-pathogen interactions, hundreds of genes are up- and downregulated. In many cases, differences between susceptibility and resistance are associated with differences in the timing and magnitude of these changes rather than with the expression of different sets of genes (141). As evident from the occurrence of mainly Arabidopsis mutants with enhanced disease susceptibility (eds) (115), plants possess a basal resistance against their pathogens, which is overcome, manipulated, or suppressed by these pathogens to allow successful infection and tissue colonization $(25,98,127,182)$. Arabidopsis mutants affected in the production or action of the signaling compounds salicylic acid (SA), jasmonic acid (JA), or ethylene (ET) likewise show an enhanced diseasesusceptibility phenotype upon infection by specific pathogens, indicating that these regulators play a role in the basal resistance against these pathogens $(77,143)$. The same regulators have also been implicated in certain types of nonhost resistance and in $R$-gene-mediated resistance, suggesting that expression of these different types of resistance involves activation of partly similar defensive mechanisms $(54,144)$. Whether or not a plant turns out to be susceptible or resistant is likely determined by the speed and magnitude with which these mechanisms are activated and expressed and by their effectiveness against individual pathogens with different modes of attack.

Because the availability of microarrays is largely limited to Arabidopsis, current views are based mostly on a few selected interactions, e.g., those of Arabidopsis with the oomycete Hyaloperonospora parasitica (87), the fungus $\mathrm{Al}$ ternaria brassicicola (156), and the bacterium Pseudomonas syringae pv. maculicola (46). Data from other plant species infected by other pathogens or attacked by insects are usually interpreted with reference to the former. Although different plant species react to infection by activation of similar defensive mechanisms, their regulation may differ in important details. For instance, basal resistance against the fungus Botrytis cinerea is regulated by SA in tomato but by JA and ET in tobacco $(1,45)$. Systemic JA-mediated induced resistance against insect herbivory in tomato involves the mobile signaling peptide systemin, but in other plant species no obvious counterpart of this transportable signal is evident (61). Such differences may be at the basis of the specificity in plant-pathogen interactions, as only a small number of potential pathogens is able to infect any given plant species.

Among the genes that in Arabidopsis are activated in response to infections, many appear to be involved in transcriptional regulation, signal transduction, various metabolic activities, and defense (32). The current status of transcription factors and signaling pathways involved in plant reactions to microorganisms has been the subject of several recent reviews $(19,38)$ and is not discussed here; neither are changes in metabolic pathways that occur during disease development, or involved in the readjustment of plant functioning, in response to an infecting pathogen. Instead, this review concentrates on inducible proteins that have been implicated in active defense and could play a role in restricting pathogen development and spread in the plant. Most of these defense-related proteins correspond to pathogenesis-related proteins (PRs) or the products of so-called SAR genes, which were identified several years ago as being associated 
with resistance reactions of plants to various pathogens $(12,149)$. The study of these proteins has now shifted almost entirely to the analysis of the expression of the corresponding genes, but the relationships between the proteins and their encoding genes are not always obvious. Defense-related proteins commonly occur as families of closely related homologues whose mRNAs may cross-hybridize to greater or lesser extents. Corresponding mRNAs in newly studied plant species are commonly identified on the basis of crosshybridization with heterologous probes. At the gene level, sequences are annotated on the basis of homology to an arbitrary member of the family without knowledge of whether and where the gene(s) are expressed. Of several proteins that are grouped within the same family on the basis of their serological relatedness and/or biological activity, the amino acid sequences are only partly known, if at all. Under these circumstances, in many cases the correspondence between genes/mRNAs and proteins is far from clear. For example, single, chemically induced PR-1, PR-2, and PR-5 proteins from Arabidopsis intercellular washing fluid were purified and characterized, and genes corresponding to these proteins were cloned and sequenced (148). However, it recently became clear that the gene annotated as $P R-1$ on the Affymetrix Arabidopsis ATH1 GeneChip (At2g19990) is actually a homolog of the PR-1 gene (At2g14610) that corresponds to the characterized protein (78). With the exception of a number of nucleotide sequences in tobacco and tomato-for which the PR-proteins have been fully classifiedit is generally unclear which gene/mRNA within a family corresponds to which protein, or whether specific genes are expressed at all.

The resulting confusion is exacerbated by the use by different authors of various designations for the same gene or protein [e.g., Table 2 in (155)]. Although a unifying nomenclature for PR-proteins was described as early as 1994 (153), classification of PRs beyond tobacco and tomato has been hampered by the paucity of data on the properties of the

\section{PR-PROTEINS IN WINE}

Grape berries accumulate PRs during ripening and as a result of induction by biotic or abiotic stress. Because PRs are resistant to proteolytic attack and low $\mathrm{pH}$, they survive vinification and can adversely affect the clarity and stability of the wine. For instance, haziness develops as a result of the presence of mainly chitinases and thaumatin-like proteins. To remove the proteins, wines are cleared by adding an adsorptive compound, followed by the settling or precipitation of partially soluble components from the wine during layering. This process may also remove important wine aroma and flavour compounds and reduce wine quality.

It is assumed that the presence of PRs in the berries contributes to basal resistance against pathogens. Thus, a benefit to the plant is a nuisance to the winemaker (40).

proteins in other plant species and the restriction of data to the mRNA (cDNA) level. Originally, PRs were classified on the basis of their characteristics as plant proteins induced in pathological or related situations. Related proteins occurring in the absence of pathogen infection were to be referred to as "PR-like" proteins (PRLs). The term PRL was not adopted by the scientific community, in part because the distinction between PRs and PRLs became blurred when it was found that specific PRs were sometimes present in healthy tissues and the levels of certain pre-existing PRLs were increased after pathogen infection. The term "pathogenesisrelated proteins" then became a collective term for all microbe-induced proteins and their homologues to the extent that enzymes such as phenylalanine ammonia-lyase (PAL), peroxidase, and polyphenoloxidase, which are generally present constitutively and only increased during most infections, are often also referred to as PRs. The latter was never intended to be the case (153), as there are numerous enzyme activities that are increased in response to pathogen attack and which may also play a role in defense (53). For this reason, in this review the general term "inducible defense-related proteins" is used to indicate
PRL: PR-like protein

PAL: phenylalanine ammonia-lyase 
Table 1 Recognized families of pathogenesis-related proteins

\begin{tabular}{|c|c|c|c|}
\hline Family & Type member & Properties & Gene symbols \\
\hline PR-1 & Tobacco PR-1a & Unknown & $Y p r 1$ \\
\hline PR-2 & Tobacco PR-2 & $\beta-1,3$-glucanase & $\operatorname{Ypr} 2,\left[G n s 2\left({ }^{\prime} G l b^{\prime}\right)\right]$ \\
\hline PR-3 & Tobacco P, Q & Chitinase type I, II, IV, V, VI, VII & Ypr3, Chia \\
\hline PR-4 & Tobacco 'R' & Chitinase type I, II & Ypr4, Chid \\
\hline PR-5 & Tobacco S & Thaumatin-like & $Y p r 5$ \\
\hline PR-6 & Tomato Inhibitor I & Proteinase-inhibitor & Ypr6, Pis ('Pin') \\
\hline PR-7 & Tomato $\mathrm{P}_{69}$ & Endoproteinase & $Y p r 7$ \\
\hline PR-8 & Cucumber chitinase & Chitinase type III & Yprs, Chib \\
\hline PR-9 & $\begin{array}{l}\text { Tobacco "lignin-forming } \\
\text { peroxidase" }\end{array}$ & Peroxidase & Ypr $9, \operatorname{Prx}$ \\
\hline PR-10 & Parsley "PR1" & Ribonuclease-like & $Y \operatorname{pr} 10$ \\
\hline PR-11 & Tobacco "class V" chitinase & Chitinase, type I & Ypr11, Cbic \\
\hline PR-12 & Radish Rs-AFP3 & Defensin & Ypr12 \\
\hline PR-13 & Arabidopsis THI2.1 & Thionin & $Y p r 13, T b i$ \\
\hline PR-14 & Barley LTP4 & Lipid-transfer protein & $Y p r 14$, Ltp \\
\hline PR-15 & Barley OxOa (germin) & Oxalate oxidase & Ypr15 \\
\hline PR-16 & Barley OxOLP & Oxalate-oxidase-like & Ypr16 \\
\hline PR-17 & Tobacco PRp27 & Unknown & $Y \operatorname{pr} 17$ \\
\hline
\end{tabular}

Further details can be found at http://www.bio.uu.nl/ fytopath/PR-families.htm.

Chitinases: enzymes that cleave poly- $\beta-1,4-\mathrm{N}$ acetylglucosamine (chitin)

Lysozyme: an enzyme that cleaves bacterial peptidoglycans

Thaumatin: a sweet protein from the fruit of the African shrub Thaumatococcus daniellii those proteins that are mostly nondetectable in healthy tissues and for which induction at the protein level has been demonstrated after infection by one or more pathogens. Inducible defense-related proteins encompass both the known PR-protein families and nonclassified proteins meeting the criteria above. The term "defense-related" refers to the fact that these proteins are induced in association with resistance responses but does not by itself imply a functional role in defense. However, because some of these proteins have at least potential antimicrobial activities, a role in resistance to pathogens appears plausible and is discussed below.

\section{FAMILIES OF}

\section{DEFENSE-RELATED PROTEINS AND THEIR OCCURRENCE}

Inducible defense-related proteins were first discovered in tobacco reacting hypersensitively to Tobacco mosaic virus (TMV) and later shown to occur in plant species from at least 13 families upon infection by oomycetes, fungi, bacteria, viruses, and viroids, as well as ne- matode or insect attack (149). The recognized PRs have been extensively reviewed (12, $29,72,75,179)$ and currently comprise 17 families of induced proteins (Table 1). The families are numbered in the order in which they were discovered. A type member, usually the first or most prominent one, was chosen and families were defined further on the basis of their common biochemical and biological properties. A role of several families in limiting pathogen activity, growth, and spread fits with the identification of the PR-2 family as $\beta$-1,3-endoglucanases and the PR$3,-4,-8$, and -11 as endochitinases, which could act against fungi. The chitinases, as well as the proteinase inhibitors (PR-6), could also target nematodes and herbivorous insects. Members of the PR-8 family also possess lysozyme activity and may be directed against bacteria, whereas defensins (PR-12) $(80,142)$ and thionins (PR-13) $(9,36)$ both have broad antibacterial and antifungal activities. Some lipid transfer proteins (PR-14) have antifungal and antibacterial activities (44) and members of the PR-1, and the thaumatinlike PR-5 families have been associated with 
activity against oomycetes. Notably, the prominent PR-1 proteins are often used as markers of the enhanced defensive state conferred by pathogen-induced systemic acquired resistance (SAR), but their biological activity has remained elusive (155). PR-7 is an endoproteinase that is the most conspicuous PR in tomato (66). It might aid in microbial cell wall dissolution. PR-9 is a specific type of peroxidase that could act in cell wall reinforcement by catalyzing lignification (104) and enhance resistance against multiple pathogens. PR-10 shows homology to ribonucleases, and some members do have weak ribonuclease activity (16). There are no other families of PRs that are directed specifically against viruses, and it has sometimes been assumed that the ribonuclease activity of PR-10type proteins points to a role in defense against these pathogens (102). However, recently an antifungal PR-4-type protein from wheat was shown to also possess ribonuclease activity (18). The families PR-15, -16, and -17 have been added recently. PR-15 and -16 are typical of monocots and comprise families of germinlike oxalate oxidases and oxalate oxidase-like proteins with superoxide dismutase activity (8), respectively. These proteins generate hydrogen peroxide that can be toxic to different types of attackers or could directly or indirectly stimulate plant-defense responses (e.g., 34, 62). PR-17 proteins have been found as an additional family of PRs in infected tobacco, wheat, and barley and contain sequences resembling the active site of zincmetalloproteinases (21), but have remained uncharacterized so far. A putative novel family (PR-18) comprises fungus- and SA-inducible carbohydrate oxidases, as exemplified by proteins with hydrogen peroxide-generating and antimicrobial properties from sunflower (27). Not all families seem to be represented in all plant species, and occurrence and properties of different members within a family may differ strongly.

The described SAR genes, whose coordinate induction correlates with the onset of SAR, encompass most $P R$ genes, as well as a protein designated SAR 8.2, whose levels are strongly increased in tobacco in response to TMV infection (169). Among other nonclassified proteins resembling $\mathrm{PRs}$ in their induction by pathogens are an amylase in tobacco (55), the DRR206 protein in pea (26), cell wall hydroxyproline-rich glycoproteins (37), glycine-rich proteins (119), polygalacturonase-inhibiting proteins (31), lipoxygenases (41), and lipase-like gene products (64). Important groups of antimicrobial proteins that are present in various plant organs but have not been reported to be induced by pathogen attack - and hence are not PRs-are ribosome-inactivating proteins, lectins, and various types of cysteine-rich peptides (12).

In leaves, PRs appear to be present both in epidermal and mesophyll cells, as well as in the vascular bundles. As an example, in response to infection by Phytophthora infestans, potato accumulates PR-1b in the vicinity of the successfully colonized leaf area and of the epidermal cell layer in particular. Additional locations within infected leaves were stomatal guard cells, glandular trichomes, crystal idioblasts and the vascular bundles (57). Many defense-related proteins are synthesized with an $\mathrm{N}$-terminal signal peptide determining translocation into the ER, followed by secretion into the apoplast. These proteins accumulate extracellularly and can be collected easily in intercellular washing fluid. PR-type proteins have been collected from xylem fluid of tomato, broccoli, rape, pumpkin, and cucumber $(17,67,111,112)$ and from guttation fluid of barley leaves (51), suggesting that secretion into the veins entails uptake and transport in the transpiration stream. Other proteins have additional extensions specifying deposition into the vacuole. PR-10-type proteins are the only family of which all members seem to be cytoplasmic.

After their characterization as proteins induced as a result of pathogen or insect attack, many of the same or closely related proteins/mRNAs have been found to be expressed in a developmentally controlled,
Systemic acquired resistance (SAR): the phenomenon that plants acquire an enhanced defensive capacity against subsequent pathogen attack as a result of a primary, limited infection 
Somatic

embryogenesis:

embryo formation as a result of dedifferentiation of diploid cells organ-specific manner in healthy plants (12, 162). Indeed, the same proteins can both appear during specific developmental stages and be induced in response to infection in the same organs (see Figure 1). For instance, pathogen-inducible basic PR-2 glucanase and PR-3 chitinase in tobacco are not detectable in young leaves of noninfected plants, but accumulate over their lifetime and are particularly abundant in roots. These and many other PRs are also present in floral organs of various plant species. PR-10-type proteins are widespread and have been found in pollen from various species. A PR-10-type protein from mung bean was reported to specifically bind cytokinin (43), whereas similar proteins from Thalictrum flavum and Hypericum perforatum function as metabolic enzymes in plant secondary metabolism (120). In addition, a general plant steroid carrier function, including brassinosteroid binding, has been suggested for PR-10-type proteins (88). A PR-2type protein has been shown to be necessary for normal pollen development in tobacco and rice (170). Moreover, basic PR-2- and PR-
3 -type proteins in tobacco, tomato, and pea seeds play a role in germination by degrading the cell walls of the seed coat and allowing the emerging radicle to protrude, or protect the exposed inner tissues of the seed against microbial entry $(83,93,172)$. In carrot, PR-3and PR-4-type chitinases are required for embryogenesis to proceed beyond the globular stage (76). A common occurrence of chitinases in embryogenic tissues has been associated with enzymatic activity on arabinogalactan proteins (e.g., 33, 105). These findings indicate that PR-type proteins can have a developmental role and, through their enzymatic activities, may generate signal molecules that could act as endogenous elicitors in morphogenesis. Such elicitors could also play a role in activating other types of defensive responses. Several PRs, such as PR-1-, -2-, -3-, and -4type proteins and proteinase inhibitors, have been shown to be induced in abscission zones (114) and might be involved in cell wall loosening or in defense of the scarified tissue to invasion by bacterial and fungal pathogens. Many pathogen-inducible proteins in leaves

Figure 1

Phylogenetic relationships and structural characteristics of predicted PR-1 proteins of Arabidopsis thaliana. All 22 proteins with a predicted PR-1 domain (Pfam code PF00188) encoded by the Arabidopsis genome were aligned with the PR-1-type protein of the fungus Fusarium graminearum (FG02744; not shown) as an outgroup for phylogenetic analysis. The gene model of AT1G50050 was adjusted (second intron removed) to improve alignment of the translation product to the other proteins. Additions to the conserved PR-1 domain at $\mathrm{N}$ termini and $\mathrm{C}$ termini were trimmed and gap-rich regions that could not be aligned unambiguously were removed. This alignment was used to construct a phylogenetic tree using neighbor-joining. Bootstrap percentages are provided only for branches receiving $60 \%$ or more support. Branch length reflects the extent of sequence divergence. The lengths of $\mathrm{N}$-terminal extensions ( $\mathrm{N}$-ext) to the core sequence are the distance between the predicted signal peptide cleavage site (SignalP) and the first residue of the conserved core (a range is given if there is more than one potential signal peptide cleavage site). C-terminal extensions to the core are given beyond the conserved sequence "P[F/Y]". Isoelectric point (pI) is given for the conserved core sequences as calculated at

http://www.expasy.org/tools/pi_tool.html. Gene clusters (i.e. homologous genes in close proximity on the same chromosome) are indicated with arbitrary letters. Boxed: the only protein with an ortholog $(\mathrm{Os} 02 \mathrm{~g} 54560)$ in rice. On the right, an overview is given of the expression of the Arabidopsis PR-1 gene family from Affymetrix ATH1 GeneChip data. $P R-1$ gene expression was analyzed upon infection by the pathogenic bacterium Pseudomonas syringae pv. tomato and fungus Alternaria brassicicola, infestation by the herbivorous insects Pieris rapae (Cabbage white butterfly), Frankliniella occidentalis (Western flower thrips), or Myzus persicae (green peach aphid), exogenous application of salicylic acid (SA: $1 \mathrm{mM}$ ) or methyl jasmonate (MeJA: $100 \mu \mathrm{M}$ ), or in different plant organs (roots, leaves, inflorescence, or pollen). Red squares indicate significant up-regulation. AT5G57625 is not represented on the ATH1 GeneChip. Gene expression data are derived from (32), and the Arabidopsis Microarray Database and Analysis Toolbox GENEVESTIGATOR (183). 


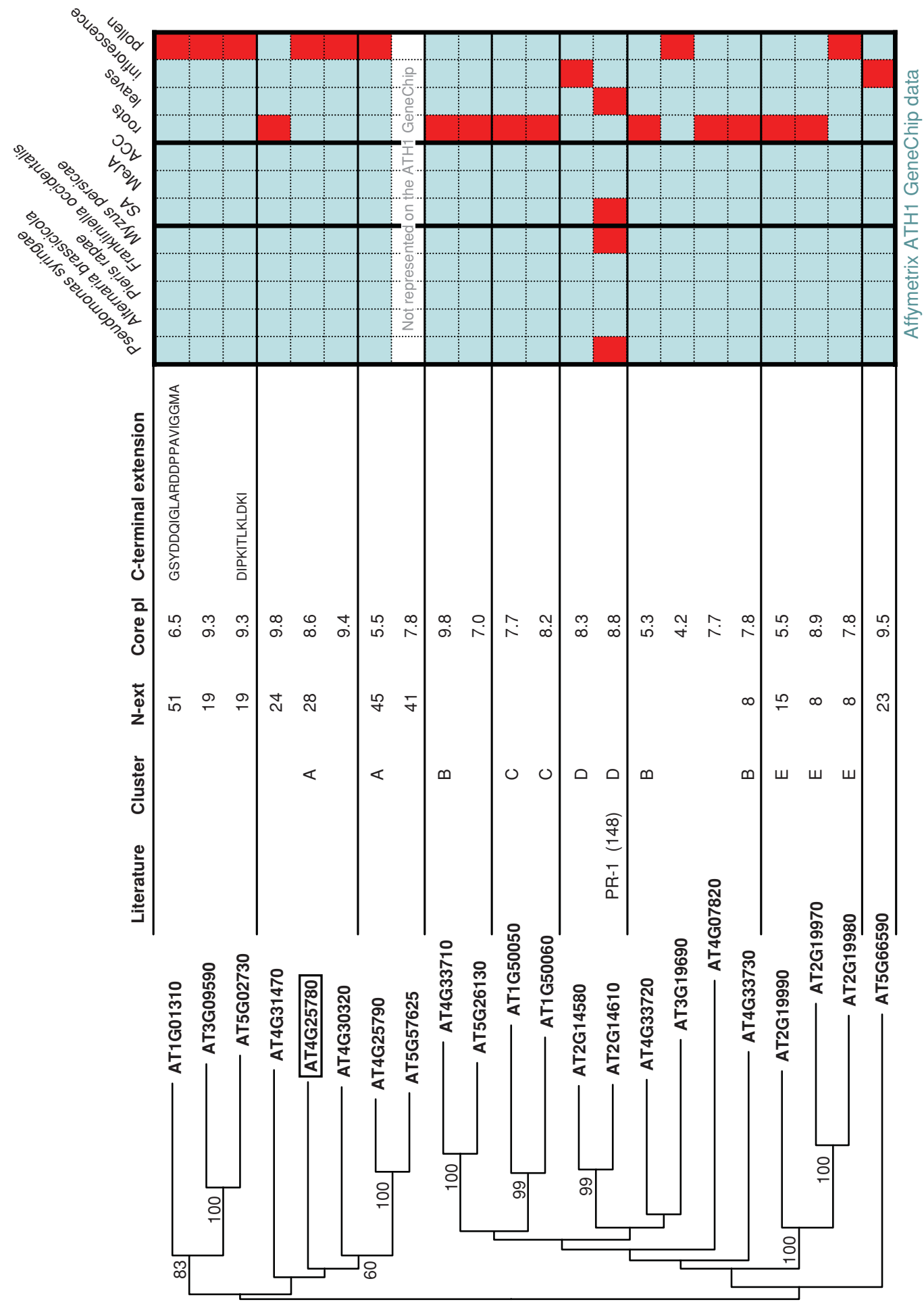


are constitutively present in storage tissues, such as fruits, seeds, and tubers $(11,131)$. This holds particularly for proteinase and amylase inhibitors, various types of lectins, defensins, thionins, and some lipid transfer proteins (12). Besides conferring protection against predation and disease (85), these proteins constitute a storage form of nitrogen (106) and might contribute to the survival of the organs during environmentally unfavorable periods.

\section{THE RELATIONSHIP BETWEEN PR-1-TYPE PROTEINS AND PLANT DEFENSE}

The PR-1 family is strongly conserved and appears to be represented in every plant species investigated to date. Homologues have been found in fungi, insects, and vertebrates, including human, but of all PR-families, its function is the least understood (155). PR1-type proteins are very similar in structure with $35 \%$ sequence identity among all PR1 proteins and pair-wise sequence identities between 56\% and 97\%. All PR-1 proteins are structurally similar in having four $\alpha-$ helices and four $\beta$-strands and share a number of strictly conserved residues, including six cysteines. These findings suggest that the unique molecular structure of PR-1 defines a protein module that has been retained during evolution and must serve one or more important functions. In tobacco (Nicotiana tabacum cv. Samsun NN) at least 16 PR-1type genes appear to be present (24). Three acidic (1a, 1b, and 1c) and one basic (1g) protein with different biological properties were identified as being induced upon TMV infection. Additional or different homologues were found in other tobacco cultivars or in related Nicotiana species. In tomato, closely related homologues of the major extracellular, acidic tobacco PR-1a, -b, and -c are basic proteins (153). These findings indicate that PRs that are classified in the same family on the basis of sequence homology can have different properties and, hence, may differ substantially in biological activity.
In vitro, tomato $\mathrm{PR}-1 \mathrm{c}$ reduced germination of sporangia and germ-tube length of $P$. infestans and, in vivo, its application reduced the surface area of leaf discs infected with this oomycete. Basic tobacco PR-1g was similarly active against this pathogen, whereas tobacco PR-1a and $-1 \mathrm{~b}$ were only marginally so (96). However, neither in tomato nor in tobacco have transgenic plants engineered to constitutively express these proteins been described to possess enhanced resistance against $P$. infestans. This does not imply that these proteins could not contribute to basal resistance against this pathogen in vivo. However, other factors may already be sufficient to achieve basal resistance, or the pathogen is less vulnerable to these defenses in vivo. Extracellular defense-related proteins are perfectly located to contact invading attackers before tissue penetration has taken place, and have been considered a possible first line of defense. However, it takes time before the proteins start to accumulate. Thus, an effective pathogen is likely to have passed into further tissues before the induced proteins become sufficiently active. Consequently, their function may be directed more against following invaders, or constitute part of the biochemical barrier raised by SAR against subsequent infections.

Developmentally regulated defenserelated proteins that are located in the vacuole could act as an effective second line of defense when the pathogen causes tissue damage. When the vacuole is disrupted, the lysosomelike contents are released and could engulf the pathogen. Many pathogens, including $P$. infestans, have a hemibiotrophic lifestyle in which, at first, they avoid damaging infected cells. Only later, when they have already colonized further tissues, the earlier infected cells collapse and massive liberation of hydrolytic enzymes occurs. Again, the plant would react too late to effectively stall the pathogen. Nevertheless, in the subtle but dynamic interplay between the pathogen and the plant, the balance may be shifted depending on the speed and magnitude of attack and defense. 
When pathogen-inducible PR-1 genes in tobacco were expressed individually under the control of the constitutive $35 \mathrm{~S}$ promoter, the transformed plants were slightly more resistant to blue mold, caused by Peronospora tabacina, and black shank, due to Phytophthora parasitica f.sp. nicotianae, but not to diseases caused by the fungus Cercospora nicotianae, the bacterium Pseudomonas syringae pv. tabaci, or several viruses (12). Overexpression of a TMV-inducible basic PR-1-encoding gene from pepper enhanced tolerance to $P$. parasitica var. nicotianae, Ralstonia solanacearum, and P. syringae pv. tabaci (121). The apparent association between PR-1 proteins and enhanced resistance against oomycetes has been noted, but too few data on nonoomycete pathogens have been reported to conclude that PR-1 is directed specifically against oomycete attack.

Such functional analysis would be greatly aided by mutant or knock-out lines in which all members of the PR-1 family were lacking or nonfunctional. Transient silencing of $P R-$ 1 expression by double-stranded RNA interference in barley allowed the mildew fungus Blumeria graminis f.sp. hordei to penetrate the cell wall more frequently (126). However, the effect was small. Given the number of PR-1 proteins in tobacco and tomato and the lack of knowledge about the number of possible genes, this has not been attempted in other species. Although known PR-1 proteins contain a widely conserved sequence encompassing the fourth $\alpha$-helix and first part of the third $\beta$-strand, CGHYTQVVW[R/K]X[S/T][V/ $\mathrm{T}][\mathrm{R} / \mathrm{S}] \mathrm{XGC}$ (155), there is insufficient homology at the nucleotide level to allow downregulation of all genes through RNA interference or virus-induced gene silencing.

In the fully sequenced genomes of $\mathrm{Ara}$ bidopsis and rice, 22 and 39 PR-1-type genes are present, respectively (Figures 1, 2). Most rice PR-1 genes are present in clusters (Figure 2). A special case is a cluster on chromosome 7 with 14 PR-1 genes. This cluster contains one full and one partial duplication of a $\sim 32-\mathrm{kb}$ genomic region containing three PR-1 genes, as well as many transposons. As a result, these three PR-1 genes have two or four exact copies in this cluster. Most of the remaining PR-1 genes in rice and about half of those in Arabidopsis are present in clusters of two to four genes, with at most four intervening genes. In several cases, but not always, clusters contain genes that are more related to each other than to the other paralogs in the genome, indicative of local duplication events.

In phylogenetic trees containing homologous proteins from both Arabidopsis and rice, only one branch was found with proteins from both species. These two, At4g25780 and Os02g54560, are likely to be orthologs. Next to relatively high similarity of their core sequences, additional evidence for orthology is that both are predicted to contain N-terminal extensions of similar length (29 and 36 residues, respectively) that contain cysteines, a feature that is not observed for any other PR-1 protein of either plant species. Paucity of mixed branches of PR-1 proteins indicates that the current complement of PR-1 proteins of Arabidopsis and rice has developed mostly independently, through loss of orthologs and gene duplications after divergence of the species. How far this can have a bearing on the antimicrobial activities of these genes is unclear. In Arabidopsis only a single PR-1 gene (At2g14610) is activated by infection, insect attack, or chemical treatment, whereas ten and eight different PR-1-type genes are constitutively expressed in roots and pollen, respectively (Figure 1). In rice, JA-inducible cDNAs corresponding to one acidic and one basic $\mathrm{PR}-1$ protein have been characterized (2), but induction of the proteins themselves upon infection has not been investigated.

The retention of the high numbers of homologues can only be explained by an important function in plant life. Recently, a $28-\mathrm{kDa}$ PR-1 family member, Tex 31, from the venom duct of the cone snail Conus textile was shown to have serine protease inhibitor-sensitive proteolytic activity, with the likely catalytic residues falling within the structurally conserved PR-1 domain (92). Similarly,
Paralogs:

homologous genes within a species

Orthologs: related genes in different species 


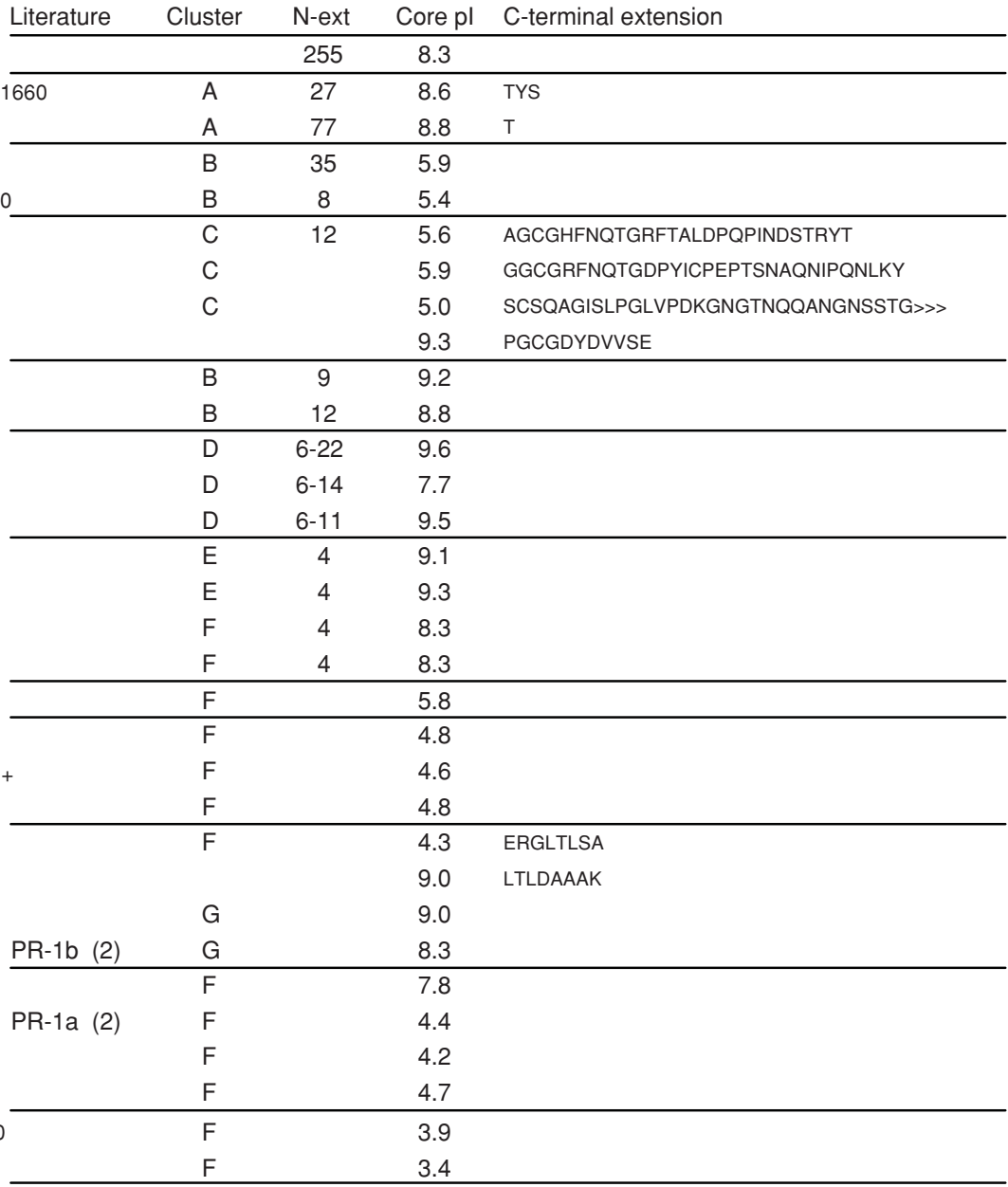

Figure 2

Phylogenetic relationships and structural characteristics of predicted PR-1 proteins of rice. All 32 proteins with a predicted PR-1 domain encoded by the rice genome were aligned with $F$. graminearum FG02744 (not shown) as an outgroup for phylogenetic analysis. Three proteins are encoded by three or four identical genes, of which only one is shown in the figure ("+" signs indicate the presence of extra copies; duplicates of Os07g03280 are Os07g03370 and Os07g03460; duplicates of Os07g03320 are Os07g03410 and Os07g03500; duplicates of Os07g03290 are Os07g03380, Os07g03470 and Os07g03590). The following gene models were adjusted to optimize alignments and/or to comply with cDNA sequences: Os07g03740 (first 5 exons removed, this is now a pseudogene due to a frameshift); Os $07 \mathrm{~g} 14070$ (disrupted by insertion of a repetitive element instead of the currently proposed intron); Os04g22210 (intron removed, different start codon); Os02g27310 (split in two PR-1 genes, provisionally called Os02g27310A and Os02g27310B). Pseudogenes are indicated with an asterisk. The C-terminal extension of Os02g27310B is much larger than shown (hence the " >>> signs) and includes a probable transmembrane segment and protein kinase domain. Boxed: the only protein with an ortholog (At4G25780) in Arabidopsis thaliana. See legend of Figure 1 for details of the phylogenetic analysis and other characteristics of the proteins listed. 
dimerization of the human Golgi-associated PR-1-type protein GAPR-1 may lead to the formation of a catalytic triad similar to that of serine proteases, across the dimer interface by residues from both molecules (129). However, others (70) consider the PR-1 fold to form a stable scaffold for biological interactions with other proteins. If such interactions occur in infected plants, they are not stable, because no complexes of PR-1 with other proteins have been identified upon native polyacrylamide gel electrophoresis (152).

\section{ACTIVITIES AND BIOLOGICAL SIGNIFICANCE OF OTHER INDUCIBLE DEFENSE-RELATED PROTEINS}

In spite of the consistent association of inducible defense-related proteins with resistance reactions, most published data on constitutively expressing transgenic plants show only limited, if any, enhanced resistance against specific pathogens. Whereas many defense-related proteins have been demonstrated to inhibit growth of selected fungi and bacteria in vitro, in most cases such results are not predictive of suppression of pathogens in planta. This may be caused by insufficient expression or instability of the protein in the transgenic plant. Another reason may be insensitivity of the pathogen toward the protein due to secretion of inhibitors (145) or the presence of protective layers around hyphal or bacterial cell walls (125) that are not present during in vitro cultivation on artificial media. However, in some cases, expression of the transgenic protein may be more effective than in in vitro tests, for instance when elicitors that are released from the pathogen activate defense responses in the plant $(10,177)$. Both glucanases and chitinases could also act on endogenous plant substrates and, thereby, aid in the generation of signal molecules that may function as endogenous elicitors of further defensive mechanisms. Thus, in vitro only indications can be obtained of the range of fungi or bacteria that might be affected by a defense- related protein when this is expressed in a transgenic plant.

Furthermore, the limitation of most tests to easily transformable plant species, such as tobacco, and their cognate pathogens, makes it difficult to generalize an effect observed.

Several types (classes) and isoforms of $\beta$ 1,3 -glucanases and chitinases with different substrate specificities and specific activities $(13,132)$ are constitutively present in plants. As a result, they can only be enhanced, rather than specifically induced, by pathogen infection, and often are increased also under other stress conditions. Although these enzymes can potentially degrade microbial cell wall components and, thereby, might contribute to the expression of resistance, causal relationships have been established only for a relatively small number of well-characterized PRtype proteins $(12,50)$. In tobacco, specific $\beta$ 1,3-glucanases from alfalfa, barley, tobacco, and soybean have been shown to suppress diseases caused by C. nicotianae and Phytophthora megasperma f.sp. medicaginis, Rhizoctonia solani, Alternaria alternata and P. parasitica f.sp. nicotianae, and P. tabacina and P. infestans, respectively. Tobacco PR-2b did not reduce infection by viruses. In fact, transformants of tobacco and Nicotiana sylvestris expressing an antisense construct of a class I $\beta-1,3-$ glucanase from the latter species (homologous to tobacco PR-2d) became less diseased than nontransformed control plants. This result is interpreted as being due to enhanced callose accumulation at the plasmodesmata, leading to more effective blockage of virus transport from cell to cell $(15,42)$. Overexpression of glucanases from soybean has been demonstrated to enhance protection of potato to $P$. infestans and kiwi to $B$. cinerea (50), whereas a glucanase from potato was reported to increase resistance in flax against Fusarium oxysporum and Fusarium culmorum (171).

$R$. solani was the first fungus shown to be suppressed in transgenic tobacco and canola overexpressing a basic PR-3-type chitinase from bean $(12,50)$. However, transgenic cucumber plants were not protected against 
$\beta$-1,3-glucanases:

enzymes that

hydrolyze $\beta-1,3$

glycosidic bonds in

linear or branched

glucans

Permatins: proteins that permeabilize

microbial

membranes

Osmotin: a basic

PR-5 protein that is

induced by osmotic

stress

Phosphomannans: phosphorylated mannose polymers

AMP: adenosine monophosphate this fungus when transformed with the same type of chitinases from bean, petunia, or tobacco, whereas tobacco plants transformed with chitinases from barley, cucumber, or tobacco were. The tobacco chitinase counteracted $R$. solani also in N. sylvestris and carrot, as well as Cercospora arachidicola in peanut, but when overexpressed in tobacco was not effective against $C$. nicotianae (116). Chitinases from rice were effective against $R$. solani and Magnaporthe grisea in rice (28), against Uncinula necator in grapevine (175), against $B$. cinerea in cucumber $(71,136)$ and chrysanthemum (138), and in Italian ryegrass against Puccinia coronata (137), but not in alfalfa against Stemphylium alfalfae, Colletotrichum trifolii, Phoma medicaginis, and P. megasperma f.sp. medicaginis. The enzymes from bean and tobacco did not counteract Alternaria cucumerina, B. cinerea, or Colletotrichum lagenarium on cucumber. The tobacco enzyme was effective in carrot against B. cinerea and Sclerotium rolfsii, but not against Alternaria radicina or Thielaviopsis basicola, whereas a similar chitinase from petunia had no effect in either carrot or cucumber. A tomato chitinase conferred protection to oilseed rape against Cylindrosporium concentricum, Phoma lingam, and Sclerotinia sclerotiorum $(12,50)$. Finally, a chitinase from Lycopersicon chilense increased resistance of tomato to Verticillium dabliae (135).

Expression of PR-8-type chitinases from tobacco, cucumber, and sugar beet in tobacco resulted in enhanced resistance against $R$. solani. The sugar beet enzyme also protected tobacco against $C$. nicotianae and birch against natural infection by Melampsoridium betulinum (birch rust) but not Pyrenopeziza betulicola (leaf spot) (103). These results indicate that effectiveness is dependent on transgene source, plant species, and pathogen sensitivity. The latter is further illustrated by observations that combinations of glucanases and chitinases can be substantially more effective in degrading fungal cell walls than each alone $(12,50,90,176)$. Notably, whereas neither glucanases nor chitinases alone were effective, simultaneous expression of tobacco PR-
$2 \mathrm{e}$ and $\mathrm{PR}-3 \mathrm{~d}$ rendered tomato resistant to Fusarium oxysporum f.sp. lycopersici and carrot to Alternaria dauci, A. radicina, Cercospora carotae, and Erysiphe heraclei (90).

The thaumatin-like PR-5 proteins belong to a larger family of proteins that includes permatins from monocot grains and can permeabilize fungal membranes (4). In Arabidopsis 24 PR-5-type genes have been annotated (82). The basic tobacco PR-5c (osmotin), which is inducible by pathogens and osmotic stress, and its homologs in tomato and potato have in vitro antioomycete activity against $P$. infestans, and transgenic tobacco and potato plants have enhanced resistance against this pathogen but not against $P$. parasitica f.sp. nicotianae. Overexpression of PR-5 genes from rice has been demonstrated to reduce infection of rice by R. solani (50), of wheat by Fusarium graminearum (20), of tobacco by A. alternata (158), and of carrot by A. dauci, Alternaria petroselini, $A$. radicina, B. cinerea, $R$. solani, and $S$. sclerotiorum (109). Osmotin from tomato protected transgenic orange plants against Phytophthora citrophthora (39).

A PR-5-type protein from corn seeds, zeamatin, has been described to inhibit mammalian trypsin and insect $\alpha$-amylase (123). However, several other thaumatin-like proteins lack these activities and the high molar ratio of zeamatin required for inhibition suggests either nonspecific complex formation or the presence of an impurity. Zeamatin, as well as chemically induced extracellular PR5 -type proteins from barley and pea leaves, bound polymeric $\beta$-1,3-glucans, whereas tobacco osmotin did not (147). Osmotin, but not zeamatin, exhibited endo- $\beta$-1,3-glucanase activity on these substrates. Analysis of other thaumatin-like proteins confirmed a general lack of correlation between antifungal activity, $\beta$-1,3-glucan binding, and $\beta$-1,3-glucan hydrolysis $(47,91)$. Thus, the main antifungal action of PR-5-type proteins must reside in a different property.

An osmotin-like protein as well as a basic chitinase in suspension-cultured potato cells were found to bind actin (140), and similar 
proteins from tobacco callus were implicated in binding cytokinin (74). Osmotin induces apoptosis in the yeast Saccharomyces cerevisiae, apparently by binding to phosphomannans in the cell wall (63), which facilitates access to a 7-transmembrane-domain receptor-like protein in the plasma membrane that regulates lipid and phosphate metabolism and is homologous to a mammalian receptor for the hormone adiponectin. Like adiponectin, osmotin activates AMP kinase in murine myocytes via adiponectin receptors, suggesting that osmotin action is receptor-mediated (94). Overexpression of the stress-related yeast PIR2 cell wall glycoprotein protected $S$. cerevisiae from the toxic action of osmotin (180), and a similar result was obtained for Fusarium oxysporum f.sp. nicotianae, allowing increased disease severity and fungal growth in tobacco seedlings (95). Thus, osmotin seems to contribute to basal resistance of tobacco against F. oxysporum f.sp. nicotianae. Other PR-5 proteins are much less active against yeast cells than osmotin but active against other fungal species (180). It seems that cell wall binding facilitates the action of osmotins and contributes to their fungal target specificity.

Four PR-5 proteins from Arabidopsis and seven from rice have extensions that end in a hydrophobic stretch that could serve as a membrane anchor (M. Rep, unpublished results), suggestive of a (temporary) attachment of these proteins to a membrane. Others contain a potential transmembrane segment followed by a kinase domain, suggestive of a function in extracellular sensing of perhaps $\beta-1,3$-glucan fragments and signal transduction. Three of these receptor-like kinases are present in Arabidopsis and two in rice. One of the PR-5-like receptor kinases from Arabidopsis is expressed constitutively at low levels in leaves and siliques and at higher levels in flower stems and roots, and has been suggested to recognize the same targets as the related PR-5 proteins (166). When expressed in creeping bentgrass, it delayed dollar spot symptoms caused by Sclerotinia homoeocarpa (52), indicating that it has antifungal activity. One PR-1 protein from rice also appears to be connected to a transmembrane region followed by a kinase domain (Figure 2). A similar fusion has been described for a pathogen-inducible tobacco PR-3-type protein (CHRK1). This receptor-like kinase may bind chitin but is devoid of chitinase activity due to an amino acid change at the active site (69). CHRK1 has been shown to interact with NtPUB4, an armadillo repeat protein in tobacco (68), and appears to be involved in a developmental signaling pathway regulating cell proliferation, differentiation, and endogenous cytokinin levels (81). These findings open up the possibility that some defense-related proteins have a role in signaling in response to pathogen attack or perhaps in developmental regulation.

Similar results have been obtained for other inducible defense-related genes, including SAR $8.2(12,50,90,176)$ and DDR206 $(167,168)$. In addition, genes encoding seedspecific antimicrobial proteins or glucanases and chitinases of microbial origin have been analyzed in vitro, as well as in transgenic plants (122). The results obtained corroborate the conclusion that resistance can be enhanced against some pathogens in some plant species. Typically, disease development is slowed, or pathogen proliferation and symptom severity are reduced, but not prevented. Given the enhanced protection afforded by combinations of defense-related genes, it could be that several proteins need to act in concert for effective resistance to be manifested.

\section{SIGNALING IN THE INDUCTION OF DEFENSE-RELATED PROTEINS}

Upon infection with various types of pathogens, defense-related genes are coordinately activated and may be expressed in both infected and noninfected tissues concomitant with the development of SAR (118). The association between accumulation of PRs, the products of the SAR genes, and SAR is often taken to represent a causal relationship, with 
Armadillo repeat: a 42-amino acid "arm" motif repeat first identified in the Drosophila segment polarity gene product armadillo ( $\beta$-catenin)

Induced systemic resistance: the phenomenon that plants acquire an enhanced defensive capacity against subsequent pathogen attack as a result of root colonization by selected strains of nonpathogenic bacteria

ISR: induced systemic resistance

AOS: active oxygen species

Lesion-mimic mutants: plants that "spontaneously" develop necrotic lesions during development or in response to variations in environmental conditions

Hevein: a chitin-binding protein from rubber latex the proteins acting as the agents responsible for the induced resistance against subsequent infection by a wide range of pathogens. However, the limited effectiveness of the proteins in transgenic plants, as discussed above, and the results that no plant engineered to constitutively express one or more defense-related genes has been shown to be more resistant against viruses, are difficult to reconcile with the generally enhanced defensive capacity of SAR-expressing plants. Moreover, pathogens such as $B$. cinerea on tobacco and $A$. brassicicola on Arabidopsis are virtually insensitive to SAR, but restricted by a different mechanism of induced resistance that is independent of the presence of inducible defense-related proteins in protected tissues $(143,146)$. This type of enhanced defensive capacity is elicited by specific strains of nonpathogenic, rootcolonizing bacteria and has been termed induced systemic resistance (ISR) (154). Like SAR, ISR is active against a broad spectrum of pathogenic fungi and bacteria but, unlike SAR, not against viruses. ISR has been studied mainly in Arabidopsis and found not to be associated with the expression of defenserelated genes (160). In the case of challenge inoculation of induced Arabidopsis plants with the leaf pathogenic bacterium $P$. syringae pv. tomato DC3000, the protection afforded by SAR usually is slightly stronger than that by ISR. Many of the pathogens investigated can be restricted by both SAR and ISR and induction of both SAR and ISR in the same plant leads to additively increased protection (157). These observations indicate that SAR and ISR are complementary types of induced resistance with partly overlapping, partly specific actions against different types of pathogens.

Many conditions have been described to induce SAR as well as defense-related proteins (150). The expression of a PR-1 gene or protein in particular is usually taken as a molecular marker to indicate that SAR was induced. All $P R-1$ genes in plants appear to be inducible by SA, and endogenous production or exogenous application of SA has been shown to be both necessary and sufficient to elicit the in- duced state (161). Pathogen-induced synthesis of SA in tobacco is considered to occur from benzoate, whereas the evidence in $\mathrm{Ara}$ bidopsis points to isochorismate as the immediate precursor (35). How synthesis of SA in infected plants is activated and regulated is not known, nor is it clear which factor(s) act as elicitors of SA production during pathogen infection. It has been suggested that active oxygen species (AOS) are involved and, indeed, tissue damage invariably leads to the production of AOS and synthesis of SA. Although SA can be transported in the plant, reciprocal graftings of transgenic NahG plants, in which SA is degraded, and nontransformed plants as rootstocks or scions, demonstrated that SA is not the translocated signal in SAR (161). Similar graftings between transgenic ethylene-insensitive tobacco plants expressing a mutant ethylene receptor gene from Arabidopsis as rootstock and nontransformed control plants as scion showed little or no SAR induction in the scion, indicating that ethylene perception is necessary for the generation, release, or transport of the mobile signal to distant tissues. Upon arrival of the mobile signal, the latter tissues must start producing SA, which induces the defense-related proteins locally (159). The nature of the mobile signal has remained elusive so far. An $\mathrm{Ara}$ bidopsis mutant, dir 1, impaired specifically in the systemic character of SAR, implicates involvement of a lipid transfer protein (86), suggesting that the mobile signal may contain a lipid moiety.

SA production has been suggested to be part of a feed-forward loop (130). Progressive damage will amplify SA production even further, and inevitably lead to induction of defense-related genes and SAR. This is precisely what happens when cells start necrotizing, such as during a hypersensitive reaction, and explains why slowly developing and expanding necrotic lesions or spots lead to such strong expression of defense-related genes and SAR. This also explains why lesionmimic mutants that are affected in very different genes but all exhibit necrotic leaves at 
some stage of development or under some environmental conditions, express inducible defense-related genes and SAR constitutively. Typically, many $\operatorname{cpr}$ (constitutively expressing PRs) mutants are lesion mimics (22) and are likely to express marker PRs and SAR because of this phenotype rather than because of a mutation in a specific step in the defense signaling pathway.

Upon hypersensitive necrosis, not only does the level of SA increase, but also JA synthesis and ET production are strongly enhanced early on (e.g., 108, 128). As a result, in addition to SA-inducible defense-related genes, such as in Arabidopsis PR-1, -2, and -5, JA- and ET-inducible genes, i.e., PR-3type basic chitinase, PR-4-type hevein-like protein, and PR-12 defensin PDF1.2, become activated (143). PDF1.2 in particular is often used as a marker for the induction of the JAand ET-dependent defense-signaling pathway (80). Induction of PDF1.2 can be limited, however, because accumulation of SA inhibits JA synthesis and action (134). ET sensitizes the tissue to respond to SA, as evidenced by a lowering of the concentration of SA that is required for PR-1 expression when Arabidopsis is exposed to ET (79). On the other hand, in tobacco induction of PR-1a by SA was reduced by simultaneous application of JA (97). The nature and extent of the cross-talk between the three defense-regulating hormones depend on the timing and magnitude of their increases, which, in turn, can be modulated through the action of the attacking pathogen (32).

Biotrophic pathogens are dependent on live tissues and avoid triggering necrosis. The enhanced disease susceptibility to biotrophic pathogens, such as the oomycete $H$. parasitica, of Arabidopsis mutants that are impaired in SA synthesis or signaling indicates that SA-dependent defenses contribute to basal resistance against these types of pathogens (143). Exogenous application of SA leads to induction of PR-1, -2 , and -5 mRNAs. Thus, SA-regulated defense-related proteins may be directed primarily against pathogens with a biotrophic lifestyle (those forming haustoria) rather than oomycetes as such (100). Little information on the effect of these proteins on biotrophs other than oomycetes is available and further clarification is needed.

Arabidopsis plants impaired in JA or ET signaling are, in general, more susceptible to necrotrophic pathogens $(45,143,164)$. SA may induce resistance against these pathogens also, but it is likely that SA-regulated defenses are important only at a stage in which the pathogen (still) behaves as a hemibiotroph. B. cinerea, a pathogen that is completely dependent on its necrotrophic lifestyle, kills the tissue in advance of tissue colonization, is insensitive to SA-regulated defenses-at least in Arabidopsis and tobacco-and is not affected by SAR. In contrast, necrosis in Arabidopsis as a result of infection by P. syringae pv. tomato follows a phase of spreading chlorosis, in which the bacterium multiplies abundantly in the infected leaves. Thus, P. syringae pv. tomato has a mixed biotrophic/necrotrophic lifestyle, and both SA- and JA/ET-regulated defenses contribute to basal resistance against this pathogen (157). JA-/ET-dependent defenses in Arabidopsis are boosted upon challenge inoculation of plants expressing rhizobacteriamediated ISR and are most effective against pathogenic bacteria and fungi with mixed biotrophic/necrotrophic and necrotrophic lifestyles $(146,154)$.

Many PR-type proteins are JA- and/or ET-inducible (150), and their occurrence can be further modulated by abscisic acid (7, 89, 113, 181). Whereas in Arabidopsis a distinction between the SA-inducible PR-1, -2, and -5 , and the JA/ET-inducible PR-3, -4, and -12 seems clear (143), in tobacco it has been demonstrated that different members within the same protein family are differentially regulated by SA and JA/ET $(97,128)$. Thus, the acidic PR-1, $-2,-3$, and -5 proteins, which are inducible by TMV and accumulate in the apoplast, are regulated primarily by SA, with ET and/or JA acting sometimes in a synergistic manner. The basic isoforms that are developmentally regulated and are present in the 
vacuole appear to be regulated and are inducible further by JA and ET, acting alone or in concert. For instance, ET-insensitive tobacco does not express basic PR-1g, $-2 \mathrm{~d}$, and $-5 \mathrm{c}$ in response to TMV infection, whereas local expression of the acidic isoforms is not affected (159). In other plant species, similar differential induction has been noted but not systematically investigated. In tomato, the basic orthologues of tobacco PR-1a, -1b, and -1c are present in the apoplast and inducible by SA, but in Arabidopsis and rice, the specific induction characteristics of the many PR-1-type proteins have not been investigated.

\section{RELEVANCE OF DEFENSE-RELATED PROTEINS IN SITUATIONS OTHER THAN PATHOGEN INFECTION}

Secreted PRs accumulate in senescing leaves of some species when yellowing is becoming apparent and in ripening fruits $(14,30,110)$, as well as in the medium of cell suspension cultures in the absence of visible necrosis (12, 139), indicating that at least some inducible defense-related proteins are produced also under specific physiological conditions. Abiotic stresses can also elicit defense-related protein induction, as in the case of osmotic stress, cold stress, or wounding (12). Typically, tobacco osmotin is induced in leaves, stems and roots by drought, high salt, or abscisic acid, as well as in leaves by wounding or UV light. Several reports show that apoplastic PR-1-type proteins, chitinases, glucanases, thaumatin-like proteins, thionins, and lipid-transfer proteins are induced during cold stress, as exemplified by results of Hon et al. (60) on cold hardening in rye showing that the accumulating PR-2, -3 , and -5 proteins have antifreeze activity. The same proteins accumulated in response to cold, short daylength, and dehydration. The chitinaseand glucanase-like proteins have both enzymatic and antifreeze activities $(6,49)$. At freezing temperatures the proteins alter ice crystal shape and reduce freezing injury by slowing the growth and recrystallization of ice (48). Similar proteins are induced under the same conditions in freezing-tolerant wheat and barley, but not in freezing-sensitive maize (3). In winter rye, similar PRs were induced by cold, by treatment with SA, and upon infection with the snow mold fungus $M i$ crodochium nivale, but only the PRs induced by cold exhibited antifreeze activity (56). Those proteins appear to be induced through the action of ethylene (178), indicating a striking parallel with the differential induction of specific PRs in other plant species.

Other abiotic stresses, such as heavy metal toxicity, are likely to induce defense-related proteins as a result of the cell-damaging action of the stimulus. In fact, induction of PRs is a common phenomenon in plants treated with millimolar concentrations of various types of chemicals that affect cell metabolism. Such results make it difficult to interpret whether induction was due to a toxic, pharmacological, or physiological effect. Even SA is toxic to plants at concentrations that are less than a factor two higher than commonly used to induce SAR. Such toxicity can be easily monitored, as stress-induced JA, ET, and enzymes such as peroxidase are increased under those conditions, in contrast to the specific induction of only some PRs by SA alone (150).

When testing for the compounds in various pollen and latex that are responsible for allergic reactions in humans, several types of PR-like proteins were found to be responsible. The major pollen allergen from birch, Bet $v 1$ (16), belongs to the PR-10 family, is present in "orbicules," protrusions on the sporopollenin coat, and is induced by both biotic and abiotic stress conditions in various plant tissues. PR-10-type proteins are widespread in plants and PR-10-type allergens are present in many foods such as fruits and vegetables. Other defense-related food allergens belong to the PR-2, $-3,-4,-5,-8$, $-12,-14$, and -15 families $(58,173)$. Rubber latex contains several PR-type protein allergens that may serve a protective function. The main latex allergens are $\operatorname{Hev} b$ 2, a 
glycosylated $\beta$-1,3-glucanase containing vacuolar targeting sequences, and a PR-3-type chitinase (174). The identification of several PR-like defense-related proteins as allergens in plant products is a cause of concern (59) and reduces the likelihood that transgenic plants with enhanced resistance as a result of $P R$ gene expression will be commercially acceptable.

\section{CONCLUSIONS AND PERSPECTIVES}

Genes encoding inducible plant defenserelated proteins, particularly PRs, comprise broad, evolutionarily conserved families with individual members differing widely in occurrence and, where known, activity. Therefore, they likely have an ancient origin with subsequent diversification to serve different functions. Those proteins that are expressed during plant development in specific stages or organs may, through their specific hydrolytic activities, contribute to the generation of signal molecules that can act as morphogenetic factors, such as chitinase in somatic embyogenesis. Some may themselves act as ligands of specific receptors and have a signaling role, as deduced from the occurrence of genes encoding contiguous PR-type-transmembrane-protein kinase domains. Other PR-like proteins can serve a role in protection of cellular structures against abiotic stress, such as the PR-type proteins with antifreeze activity. Whether these are original functions from which an association with defense against pathogens was derived, or the reverse, is unclear. However, their widespread induction upon pathogen attack and their regulation by the defense regulatory hormones SA, JA, and ET suggest that they play an important role in alleviating the effects of attack by pathogens and insects, as well as some forms of abiotic stress. In several instances, quantitative resistance against pathogens has been shown to be associated with constitutively expressed PRs (84, 107, 165). Adult plants growing in the field without any signs of disease often contain readily de- tectable levels of PRs (L.C. van Loon, unpublished observations), suggesting that they have experienced stress conditions. There are several reports that apparently nonpathogenic microorganisms present on leaves or in soil can increase activities of, for example, chitinase, glucanase, PAL, peroxidase, and/or polyphenoloxidase systemically in plants (151). Therefore, plants seem to constantly adjust their defensive status to the dynamically changing environment.

Because only some members of the families of defense-related proteins have a suppressive effect on some pathogens but not others, their role in restricting pathogen growth and tissue colonization appears limited. However, they appear to be part of a far larger array of SA-, JA-, and ET-dependent defenses in which each component could contribute more or less to basal resistance against an attacker, as well as to the enhanced resistance in plants with induced resistance. In SAR, the presence of induced PR-type proteins is likely to contribute to some extent to the enhanced defensive capacity. In contrast, in ISR, no defense-related proteins are present in induced leaves before challenge, but upon infection activation of JA-responsive genes in particular is accelerated and enhanced, a phenomenon known as priming (23).

Plants are able to recognize microbial invaders through specific surface determinants, collectively called pathogen-associated molecular patterns (PAMPs) and to react through defense signaling cascades $(5,99)$. Although a causal connection between recognition of nonpathogenic microorganisms and specific inducible defense-related proteins has not been established so far, broad-spectrum effectiveness of the induced resistance responses suggests that PR-type and similar proteins are part of an immune surveillance mechanism that protects the plant primarily against invasion by microorganisms that are generally perceived as nonpathogenic. Many saprophytic fungi appear more sensitive to the action of lytic enzymes, such as glucanases and chitinases, than are pathogens that are adapted
PAMPs:

pathogen-associated molecular patterns 
to attack living plants (124). Indeed, certain pathogens have been shown to be insensitive to the action of defense-related proteins from their host. For instance, Cladosporium fulvum is not sensitive to the chitinase and $\beta-1,3-$ glucanase of its host, tomato (65). Phytophthora sojae specifically inhibits the glucanase activity of its host, soybean, by producing inhibitor proteins (117). Fusarium solani f.sp. eumartii degrades PRs in the intercellular fluid from potato (101). Similarly, constitutive expression of various PRs in tobacco did not affect colonization by the beneficial mycorrhizal fungus Glomus mosseae (163).

Mutant or transgenic plants with reduced sensitivity to either JA or ET become sponta- neously infected by normally nonpathogenic fungi when grown in commercial potting soil $(73,164)$. A surveillance system based on antimicrobial proteins appears very similar to the innate immunity of vertebrates and insects, in which there are signaling cascades comprising components very similar to those involved in plant resistance signaling (99). Although the details of these systems and the nature of the antimicrobial polypeptides differ substantially between animals and plants, there appears to be a basic similarity in the innate immune responses that allow plants to flourish and us as human beings to exploit and enjoy the world of plants around us.

\section{SUMMARY POINTS}

1. Microarray analyses have shown that in both compatible and incompatible plantpathogen interactions, hundreds of genes are up- or downregulated, but only a limited number of inducible defense-related proteins have been characterized.

2. Pathogenesis-related (PR) and similar proteins have been found to be inducible by infection with various types of pathogens in many plant families and have been classified into 17 families.

3. Upon pathogen or insect attack, many defense-related proteins are inducible by the signaling compounds salicylic acid, jasmonic acid, or ethylene, whereas other plant hormones, such as abscisic acid, can modulate expression.

4. Accumulation of PRs is a hallmark of pathogen-induced systemic acquired resistance, but no defense-related proteins are detectable in plants with rhizobacteria-induced systemic resistance, in spite of a similar enhanced defensive capacity of the plants. However, in both cases, upon challenge inoculation with a pathogen, defense-related genes are expressed faster and to higher levels, a phenomenon called priming.

5. Most inducible defense-related proteins possess antimicrobial activity against fungi and bacteria in vitro, but when expressed in transgenic plants reduce only a limited number of diseases, depending on the nature of the protein, plant species, and pathogen involved.

6. Arabidopsis and rice contain 22 and 39 PR-1-type genes, but only 1 and 2, respectively, have been found to be inducible by pathogens or insect attack. Many other PR-1 genes are expressed constitutively in roots or floral tissues, indicative of a role in plant development.

7. Defense-related proteins can be induced also by wounding and cold treatment. Some PRs can modulate ice crystal formation and have antifreeze activity. 
8. Many constitutively expressed PRs in fruits, vegetables, and pollen can act as allergens, raising questions as to the possible impact of transgenic plants expressing antimicrobial proteins for enhanced disease resistance.

\section{LITERATURE CITED}

1. Achuo EA, Audenaert K, Meziane H, Höfte M. 2004. The salicylic acid-dependent defence pathway is effective against different pathogens in tomato and tobacco. Plant Pathol. 53:65-72

2. Agrawal GK, Rakwal R, Jwa N-S. 2000. Rice (Oryza sativa L.) OsPR1b gene is phytohormonally regulated in close interaction with light signals. Biochem. Biophys. Res. Commun. 278:290-98

3. Antikainen M, Griffith M. 1997. Antifreeze protein accumulation in freezing-tolerant cereals. Physiol. Plant. 99:423-32

4. Anžlovar S, Dermastia M. 2003. The comparative analysis of osmotins and osmotin-like PR-5 proteins. Plant Biol. 5:116-24

5. Asai T, Tena G, Plotnikova J, Willmann MR, Chiu WL, et al. 2002. MAP kinase signalling cascade in Arabidopsis innate immunity. Nature 415:977-83

6. Atici Ö, Nalbantoğlu B. 2003. Antifreeze proteins in higher plants. Phytochemistry 64:1187-96

7. Audenaert K, De Meyer GB, Höfte MM. 2002. Abscisic acid determines basal susceptibility of tomato to Botrytis cinerea and suppresses salicylic acid-dependent signaling mechanisms. Plant Physiol. 128:491-501

8. Bernier F, Berna A. 2001. Germins and germin-like proteins: plant do-all proteins. But what do they do exactly? Plant Physiol. Biochem. 39:545-54

9. Bohlmann H. 1994. The role of thionins in plant protection. Crit. Rev. Plant Sci. 13:1-16

10. Boller T. 1995. Chemoperception of microbial signals in plant cells. Annu. Rev. Plant Physiol. Plant Mol. Biol. 46:189-214

11. Broekaert WF, Cammue BPA, De Bolle MFC, Thevissen K, De Samblanx GW, et al. 1997. Antimicrobial peptides from plants. Crit. Rev. Plant Sci. 16:297-323

12. Broekaert WF, Terras FRG, Cammue BPA. 2000. Induced and preformed antimicrobial proteins. See Ref. 133, pp. 371-477

13. Brunner F, Stintzi A, Fritig B, Legrand M. 1998. Substrate specificities of tobacco chitinases. Plant 7. 14:225-34

14. Buchanan-Wollaston V, Earl S, Harrison E, Mathas E, Navabpour S, et al. 2003. The molecular analysis of leaf senescence-a genomics approach. Plant Biotechnol. 7. 1:3-22

15. Bucher GL, Tarina C, Heinlein M, Di Serio F, Meins F, et al. 2001. Local expression of enzymatically active class I $\beta$-1,3-glucanase enhances symptoms of TMV infection in tobacco. Plant 7. 28:361-69

16. Bufe A, Spangfort MD, Kahlert H, Schlaak M, Becker W-M. 1996. The major birch pollen allergen, Bet v 1, shows ribonuclease activity. Planta 199:413-15

17. Buhtz A, Kolasa A, Arlt K, Walz C, Kehr J. 2004. Xylem sap protein composition is conserved among different plant species. Planta 219:610-18

18. Caporale C, Di Bernardino I, Leonardi L, Bertini L, Cascone A, et al. 2004. Wheat pathogenesis-related proteins of class 4 have ribonuclease activity. FEBS Lett. 575:71-76
12. An authoritative review on occurrence, structure and properties of the different types of antimicrobial proteins in plants, including inducible defense-related proteins. 
23. Within this short review it is outlined that JAand ET-dependent priming of defense-related gene expression rather than accumulation of defense-related proteins is characteristic of rhizobacteriainduced systemic resistance.

29. This book comprehensively summarizes the characteristics and potential roles of PR families 1 to 11 as well as other inducible defense-related proteins.

35. The most recent review on SAR signaling and the role of $\mathrm{SA}$ in the activation of $P R$ genes.
19. Chen WJ, Zhu T. 2004. Networks of transcription factors with roles in environmental stress response. Trends Plant Sci. 9:591-96

20. Chen WP, Chen PD, Liu DJ, Kynast R, Friebe B, et al. 1999. Development of wheat scab symptoms is delayed in transgenic wheat plants that constitutively express a rice thaumatin-like protein gene. Theor. Appl. Genet. 99:755-60

21. Christensen AB, Ho Cho B, Naesby M, Gregersen PL, Brandt J, et al. 2002. The molecular characterization of two barley proteins establishes the novel PR-17 family of pathogenesis-related proteins. Mol. Plant Pathol. 3:135-44

22. Clarke JD, Volko SM, Ledford H, Ausubel FM, Dong X. 2000. Roles of salicylic acid, jasmonic acid, and ethylene in $c p r$-induced resistance in Arabidopsis. Plant Cell 12:217590

23. Conrath U, Pieterse CMJ, Mauch-Mani B. 2002. Priming in plant-pathogen interactions. Trends Plant Sci. 7:210-16

24. Cornelissen BJC, Horowitz J, Van Kan JAL, Goldberg RB, Bol JF. 1987. Structure of tobacco genes encoding pathogenesis-related proteins from the PR-1 group. Nucleic Acids Res. 15:6799-811

25. Cui J, Bahrami AK, Pringle EG, Hernandez-Guzman G, Bender CL, et al. 2005. Pseudomonas syringae manipulates systemic plant defenses against pathogens and herbivores. Proc. Natl. Acad. Sci. USA 102:1791-96

26. Culley DE, Horovitz D, Hadwiger LA. 1995. Molecular characterization of diseaseresistance response gene DRR206-d from Pisum sativum (L.). Plant Physiol. 107:301-2

27. Custers JHHV, Harrison SJ, Sela-Buurlage MB, Van Deventer E, Lageweg W, et al. 2004. Isolation and characterization of a class of carbohydrate oxidases from higher plants, with a role in active defence. Plant 7. 39:147-60

28. Datta K, Tu JM, Oliva N, Ona I, Velazhahan R, et al. 2001. Enhanced resistance to sheath blight by constitutive expression of infection-related rice chitinase in transgenic elite indica rice cultivars. Plant Sci. 160:405-14

29. Datta SK, Muthukrishnan S. 1999. Pathogenesis-Related Proteins in Plants. Boca Raton, FL: CRC Press. 288 pp.

30. Davoine C, Le Deunff E, Ledger N, Avice J-C, Billard J-P, et al. 2001. Specific and constitutive expression of oxalate oxidase during the ageing of leaf sheaths of ryegrass stubble. Plant Cell Environ. 24:1033-43

31. De Lorenzo G, D'Ovidio R, Cervone F. 2001. The role of polygalacturonase-inhibiting proteins (Pgips) in defense against pathogenic fungi. Annu. Rev. Phytopathol. 39:313-35

32. De Vos M, Van Oosten VR, van Poecke RMP, Van Pelt JA, Pozo MJ, et al. 2005. Signal signature and transcriptome changes of Arabidopsis during pathogen and insect attack. Mol. Plant-Microbe Interact. 18:923-37

33. Domon J-M, Neutelings G, Roger D, David A, David H. 2000. A basic chitinase-like protein secreted by embryogenic tissues of Pinus caribaea acts on arabinogalactan proteins extracted from the same cell lines. 7. Plant Physiol. 156:33-39

34. Donaldson PA, Anderson T, Lane BG, Davidson AL, Simmonds DH. 2001. Soybean plants expressing an active oligomeric oxalate oxidase from the wheat $g f-2.8$ (germin) gene are resistant to the oxalate-secreting pathogen Sclerotina sclerotiorum. Physiol. Mol. Plant Pathol. 59:297-307

35. Durrant WE, Dong X. 2004. Systemic acquired resistance. Annu. Rev. Phytopathol. 42:185-209

36. Epple P, Apel K, Bohlmann H. 1997. Overexpression of an endogenous thionin enhances resistance of Arabidopsis against Fusarium oxysporum. Plant Cell 9:509-20 
37. Esquerré-Tugayé M-T, Campargue C, Mazau D. 1999. The response of plant cell wall hydroxyproline-rich glycoproteins to microbial pathogens and their elicitors. See Ref. 29 , pp. $157-70$

38. Eulgem T. 2005. Regulation of the Arabidopsis defense transcriptome. Trends Plant Sci. 10:71-78

39. Fagoaga C, Rodrigo I, Conejero V, Hinarejos C, Tuset JJ, et al. 2001. Increased tolerance to Phytophthora citrophthora in transgenic orange plants constitutively expressing a tomato pathogenesis related protein PR-5. Mol. Breed. 7:175-85

40. Ferreira RB, Monteiro SS, Piçarra-Pereira MA, Teixeira AR. 2004. Engineering grapevine for increased resistance to fungal pathogens without compromising wine stability. Trends Biotechnol. 22:168-73

41. Feussner I, Wasternack C. 2002. The lipoxygenase pathway. Annu. Rev. Plant Biol. 53:27597

42. Fridborg I, Grainger J, Page A, Coleman M, Findlay K, et al. 2003. TIP, a novel host factor linking callose degradation with the cell-to-cell movement of Potato virus X. Mol. Plant-Microbe Interact. 16:132-40

43. Fujimoto Y, Nagata R, Fukasawa H, Yano K, Azuma M, et al. 1998. Purification and cDNA cloning of cytokinin-specific binding protein from mung bean (Vigna radiata). Eur. 7. Biochem. 258:794-802

44. García-Olmedo F, Molina A, Segura A, Moreno M. 1995. The defensive role of nonspecific lipid-transfer proteins in plants. Trends Microbiol. 3:72-74

45. Geraats BPJ, Bakker PAHM, Lawrence CB, Achuo EA, Höfte M, et al. 2003. Ethyleneinsensitive tobacco shows differentially altered susceptibility to different pathogens. Phytopathology 93:813-21

46. Glazebrook J, Chen W, Estes B, Chang H-S, Nawrath C, et al. 2003. Topology of the network integrating salicylate and jasmonate signal transduction derived from global expression phenotyping. Plant F. 34:217-28

47. Grenier J, Potvin C, Trudel J, Asselin A. 1999. Some thaumatin-like proteins hydrolyse polymeric $\beta$-1,3-glucans. Plant 7. 19:473-80

48. Griffith M, Lumb C, Wiseman SB, Wisniewski M, Johnson RW, et al. 2005. Antifreeze proteins modify the freezing process in planta. Plant Physiol. 138:330-40

49. Griffith M, Yaish MWF. 2004. Antifreeze proteins in overwintering plants: a tale of two activities. Trends Plant Sci. 9:399-405

50. Grover A, Gowthaman R. 2003. Strategies for development of fungus-resistant transgenic plants. Curr. Sci. 84:330-40

51. Grunwald I, Rupprecht I, Schuster G, Kloppstech K. 2003. Identification of guttation fluid proteins: the presence of pathogenesis-related proteins in non-infected barley plants. Physiol. Plant. 119:192-202

52. Guo Z, Bonos S, Meyer WA, Day PR, Belanger FC. 2003. Transgenic creeping bentgrass with delayed dollar spot symptoms. Mol. Breed. 11:95-101

53. Hammond-Kosack KE, Jones JDG. 1996. Resistance gene-dependent plant defense responses. Plant Cell 8:1773-91

54. Heath MC. 2002. Nonhost resistance in plants to microbial pathogens. In Infectious Disease: Innate Immunity, ed. RAB Ezekowitz, JA Hoffmann, pp. 47-57. Totowa, NJ: Humana

55. Heitz T, Geoffroy P, Fritig B, Legrand M. 1991. Two apoplastic $\alpha$-amylases are induced in tobacco by virus infection. Plant Physiol. 97:651-56

56. Hiilovaara-Teijo M, Hannukkala A, Griffith M, Yu X-M, Pihakaski-Maunsbach K. 1999. Snow-mold-induced apoplastic proteins in winter rye leaves lack antifreeze activity. Plant Physiol. 121:665-73
49. A short review describing that various defense-related proteins in a wide range of overwintering plants also have a role in protecting plants against low freezing temperatures by inhibiting the growth and recrystallization of ice. 
57. A thorough analysis of the temporal and spatial pattern of PR-1b protein and mRNA distribution in healthy and infected potato tissues.

58. An overview describing and discussing the occurrence and properties of plant-derived allergens that turned out to be similar to PRs from several different protein families.
57. Hoegen E, Strömberg A, Pihlgren U, Kombrink E. 2002. Primary structure and tissue-specific expression of the pathogenesis-related protein PR-1b in potato. Mol. Plant Pathol. 3:329-45

58. Hoffmann-Sommergruber K. 2000. Plant allergens and pathogenesis-related proteins-What do they have in common? Int. Arch. Allergy Immunol. 122:155-66

59. Hoffmann-Sommergruber K. 2002. Pathogenesis-related (PR)-proteins identified as allergens. Biochem. Soc. Trans. 30:930-35

60. Hon W-C, Griffith M, Mlynarz A, Kwok YC, Yang DSC. 1995. Antifreeze proteins in winter rye are similar to pathogenesis-related proteins. Plant Physiol. 109:879-89

61. Howe GA. 2005. Jasmonates as signals in the wound response. 7. Plant Growth Regul. 23:223-37

62. Hu X, Bidney DL, Yalpani N, Duvick JP, Crasta O, et al. 2003. Overexpression of a gene encoding hydrogen peroxide-generating oxalate oxidase evokes defense responses in sunflower. Plant Physiol. 133:170-81

63. Ibeas JI, Lee H, Damsz B, Prasad DT, Pardo JM, et al. 2000. Fungal cell wall phosphomannans facilitate the toxic activity of a plant PR-5 protein. Plant f. 23:375-83

64. Jakab G, Manrique A, Zimmerli L, Métraux J-P, Mauch-Mani B. 2003. Molecular characterization of a novel lipase-like pathogen-inducible gene family of Arabidopsis. Plant Physiol. 132:2230-39

65. Joosten MHAJ, Verbakel HM, Nettekoven ME, Van Leeuwen J, Van der Vossen RTM, et al. 1995. The phytopathogenic fungus Cladosporium fulvum is not sensitive to the chitinase and $\beta-1,3$-glucanase defence proteins of its host, tomato. Physiol. Mol. Plant Pathol. 46:4559

66. Jordá L, Conejero V, Vera P. 2000. Characterization of P69E and P69F, two differentially regulated genes encoding new members of the subtilisin-like proteinase family from tomato plants. Plant Physiol. 122:67-73

67. Kehr J, Buhtz A, Giavalisco P. 2005. Analysis of xylem sap proteins from Brassica napus. BMC Plant Biol. 5:11

68. Kim M, Cho HS, Kim D-M, Lee JH, Pai H-S. 2003. CHRK1, a chitinase-related receptor-like kinase, interacts with NtPUB4, an armadillo repeat protein, in tobacco. Biochim. Biophys. Acta 1651:50-59

69. Kim YS, Lee JH, Yoon GM, Cho HS, Park S-W, et al. 2000. CHRK1, a chitinase-related receptor-like kinase in tobacco. Plant Physiol. 123:905-15

70. Kirby TW, Mueller GA, DeRose EF, Lebetkin MS, Meiss G, et al. 2002. The nuclease A inhibitor represents a new variation of the rare PR-1 fold. F. Mol. Biol. 320:771-82

71. Kishimoto K, Nishizawa Y, Tabei Y, Hibi T, Nakajima M, et al. 2002. Detailed analysis of rice chitinase gene expression in transgenic cucumber plants showing different levels of disease resistance to gray mold (Botrytis cinerea). Plant Sci. 162:655-62

72. Kitajima S, Sato F. 1999. Plant pathogenesis-related proteins: molecular mechanisms of gene expression and protein function. F. Biochem. 125:1-8

73. Knoester M, Van Loon LC, Van den Heuvel J, Hennig J, Bol JF, et al. 1998. Ethyleneinsensitive tobacco lacks nonhost resistance against soil-borne fungi. Proc. Natl. Acad. Sci. USA 95:1933-37

74. Kobayashi K, Fukuda M, Igarashi D, Sunaoshi M. 2000. Cytokinin-binding proteins from tobacco callus share homology with osmotin-like protein and an endochitinase. Plant Cell Physiol. 41:148-57

75. Kombrink E, Somssich IE. 1997. Pathogenesis-related proteins and plant defense. In The Mycota V, Part A. Plant Relationships, ed. G Carroll, P Tudzynski, pp. 107-28. Berlin: Springer-Verlag 
76. Kragh KM, Hendriks T, De Jong AJ, Lo Schiavo F, Bucherna N, et al. 1996. Characterization of chitinases able to rescue somatic embryos of the temperature-sensitive carrot variant ts11. Plant Mol. Biol. 31:631-45

77. Kunkel BN, Brooks DM. 2002. Cross talk between signaling pathways in pathogen defense. Curr. Opin. Plant Biol. 5:325-31

78. Laird J, Armengaud P, Giuntini P, Laval V, Milner JJ. 2004. Inappropriate annotation of a key defence marker in Arabidopsis: Will the real PR-1 please stand up? Planta 219:1089_ 92

79. Lawton KA, Potter SL, Uknes S, Ryals J. 1994. Acquired resistance signal transduction in Arabidopsis is ethylene independent. Plant Cell 6:581-88

80. Lay FT, Anderson MA. 2005. Defensins—components of the innate immune system in plants. Curr. Protein Pept. Sci. 6:85-101

81. Lee JH, Takei K, Sakakibara H, Cho HS, Kim DM, et al. 2003. CHRK1, a chitinaserelated receptor-like kinase, plays a role in plant development and cytokinin homeostasis in tobacco. Plant Mol. Biol. 53:877-90

82. Léon-Kloosterziel KM, Verhagen BWM, Keurentjes JJB, Van Pelt JA, Rep M, et al. 2005. Colonization of the Arabidopsis rhizosphere by fluorescent Pseudomonas spp. activates a root-specicific, ethylene-responsive $P R-5$ gene in the vascular bundle. Plant Mol. Biol. 57:731-48

83. Leubner-Metzger G. 2005. $\beta$-1,3-glucanase gene expression in low-hydrated seeds as a mechanism for dormancy release during tobacco after-ripening. Plant 7. 41:133-45

84. Liu B, Zhang S, Zhu X, Yang Q, Wu S, et al. 2004. Candidate defense genes as predictors of quantitative blast resistance in rice. Mol. Plant-Microbe Interact. 17:1146-52

85. Lozovaya VV, Waranyuwat A, Widholm JM. 1998. $\beta$-1,3-glucanase and resistance to Aspergillus flavus infection in maize. Crop Sci. 38:1255-60

86. Maldonado AM, Doerner P, Dixon RA, Lamb CJ, Cameron RK. 2002. A putative lipid transfer protein involved in systemic resistance signalling in Arabidopsis. Nature 419:399_ 403

87. Maleck K, Levine A, Eulgem T, Morgan A, Schmid J, et al. 2000. The transcriptome of Arabidopsis thaliana during systemic acquired resistance. Nat. Genet. 26:403-10

88. Markovic-Housley Z, Degano M, Lamba D, Von Roepenack-Lahaye E, Clemens S, et al. 2003. Crystal structure of a hypoallergenic isoform of the major birch pollen allergen Bet v 1 and its likely biological function as a plant steroid carrier. 7. Mol. Biol. 325:123-33

89. Mauch-Mani B, Mauch F. 2005. The role of abscisic acid in plant-pathogen interactions. Curr. Opin. Plant Biol. 8:409-14

90. Melchers LS, Stuiver MH. 2000. Novel genes for disease-resistance breeding. Curr. Opin. Plant Biol. 3:147-52

91. Menu-Bouaouiche L, Vriet C, Peumans WJ, Barre A, Van Damme EJM, Rougé P. 2003. A molecular basis for the endo- $\beta 1,3$-glucanase activity of the thaumatin-like proteins from edible fruits. Biochimie 85:123-31

92. Milne TJ, Abbenante G, Tyndall JDA, Halliday J, Lewis RJ. 2003. Isolation and characterization of a cone snail protease with homology to CRISP proteins of the pathogenesisrelated protein superfamily. F. Biol. Chem. 278:31105-10

93. Morohashi Y, Matsushima H. 2000. Development of $\beta$-1,3-glucanase activity in germinated tomato seeds. 7. Exp. Bot. 51:1381-87

94. Narasimhan ML, Coca MA, Jin J, Yamauchi T, Ito Y, et al. 2005. Osmotin is a homolog of mammalian adiponectin and controls apoptosis in yeast through a homolog of mammalian adiponectin receptor. Mol. Cell 17:171-80
94. The latest contribution in a series of papers on the mechanism of the antifungal activity of the PR-5 protein osmotin, indicating that binding to fungal cell walls, membrane permeabilization and defense signaling may all play a role. 
95. Narasimhan ML, Lee H, Damsz B, Singh NK, Ibeas JI, et al. 2003. Overexpression of a cell wall glycoprotein in Fusarium oxysporum increases virulence and resistance to a plant PR-5 protein. Plant 7. 36:390-400

96. Niderman T, Genetet I, Bruyère T, Gees R, Stintzi A, et al. 1995. Pathogenesis-related PR-1 proteins are antifungal; isolation and characterization of three 14-kilodalton proteins of tomato and of a basic PR-1 of tobacco with inhibitory activity against Phytophthora infestans. Plant Physiol. 108:17-27

97. Niki T, Mitsuhara I, Seo S, Ohtsubo N, Ohashi Y. 1998. Antagonistic effect of salicylic acid and jasmonic acid on the expression of pathogenesis-related (PR) protein genes in wounded mature tobacco leaves. Plant Cell Physiol. 39:500-7

98. Nomura K, Melotto M, He S-Y. 2005. Suppression of host defense in compatible plantPseudomonas syringae interactions. Curr. Opin. Plant Biol. 8:361-68

99. Nürnberger T, Brunner F, Kemmerling B, Piater L. 2004. Innate immunity in plants and animals: striking similarities and obvious differences. Immunol. Rev. 198:249-66

100. Oliver RP, Ipcho SVS. 2004. Arabidopsis pathology breathes new life into the necrotrophsvs.-biotrophs classification of fungal pathogens. Mol. Plant Pathol. 5:347-52

101. Olivieri F, Zanetti ME, Oliva CR, Covarrubias AA, Casalongué CA. 2002. Characterization of an extracellular serine protease of Fusarium eumartii and its action on pathogenesis related proteins. Eur. F. Plant Pathol. 108:63-72

102. Park C-J, Kim K-J, Shin R, Park JM, Shin Y-C, Paek K-H. 2004. Pathogenesis-related protein 10 isolated from hot pepper functions as a ribonuclease in an antiviral pathway. Plant 7. 37:186-98

103. Pasonen H-L, Seppänen S-K, Degefu Y, Rytkönen A, Von Weissenberg K, Pappinen A. 2004. Field performance of chitinase transgenic silver birches (Betula pendula): resistance to fungal diseases. Theor. Appl. Genet. 109:562-70

104. Passardi F, Penel C, Dunand C. 2004. Performing the paradoxical: How plant peroxidases modify the cell wall. Trends Plant Sci. 9:534-40

105. Petruzzelli L, Kunz C, Waldvogel R, Meins F, Leubner-Metzger G. 1999. Distinct ethylene- and tissue-specific regulation of $\beta-1,3$-glucanases and chitinases during pea seed germination. Planta 209:195-201

106. Peumans WJ, Proost P, Swennen RL, Van Damme EJM. 2002. The abundant class III chitinase homolog in young developing banana fruits behaves as a transient vegetative storage protein and most probably serves as an important supply of amino acids for the synthesis of ripening-associated proteins. Plant Physiol. 130:1063-72

107. Pflieger S, Palloix A, Caranta C, Blattes A, Lefebvre V. 2001. Defense response genes colocalize with quantitative disease resistance loci in pepper. Theor. Appl. Genet. 103:920-29

108. Pieterse CMJ, Van Pelt JA, Ton J, Parchmann S, Mueller MJ, et al. 2000. Rhizobacteriamediated induced systemic resistance (ISR) in Arabidopsis requires sensitivity to jasmonate and ethylene but is not accompanied by an increase in their production. Physiol. Mol. Plant Pathol. 57:123-34

109. Punja ZK. 2005. Transgenic carrots expressing a thaumatin-like protein display enhanced resistance to several fungal pathogens. Can. F. Plant Pathol. 27:291-96

110. Quirino BF, Noh Y-S, Himelblau E, Amasino RM. 2000. Molecular aspects of leaf senescence. Trends Plant Sci. 5:278-82

111. Rep M, Dekker HL, Vossen JH, De Boer AD, Houterman PM, et al. 2003. A tomato xylem sap protein represents a new family of small cysteine-rich proteins with structural similarity to lipid transfer proteins. FEBS Lett. 534:82-86 
112. Rep M, Dekker HL, Vossen JH, De Boer AD, Houterman PM, et al. 2002. Mass spectrometric identification of isoforms of PR proteins in xylem sap of fungus-infected tomato. Plant Physiol. 130:904-17

113. Rezzonico E, Flury N, Meins F, Beffa R. 1998. Transcriptional down-regulation by abscisic acid of pathogenesis-related $\beta$-1,3-glucanase genes in tobacco cell cultures. Plant Physiol. 117:585-92

114. Roberts JA, Whitelaw CA, Gonzalez-Carranza ZH, McManus MT. 2000. Cell separation processes in plants-models, mechanisms and manipulation. Ann. Bot. 86:223-35

115. Rogers EE, Ausubel FM. 1997. Arabidopsis enhanced disease susceptibility mutants exhibit enhanced susceptibility to several bacterial pathogens and alterations in $P R-1$ gene expression. Plant Cell 9:305-16

116. Rohini VK, Rao KS. 2001. Transformation of peanut (Arachis hypogaea L.) with tobacco chitinase gene: variable response of transformants to leaf spot disease. Plant Sci. 160:88998

117. Rose JKC, Ham K-S, Darvill AG, Albersheim P. 2002. Molecular cloning and characterization of glucanase inhibitor proteins: coevolution of a counterdefense mechanism by plant pathogens. Plant Cell 14:1329-45

118. Ryals JA, Neuenschwander UH, Willits MG, Molina A, Steiner H-Y, et al. 1996. Systemic acquired resistance. Plant Cell 8:1808-19

119. Sachetto-Martins G, Franco LO, De Oliveira DE. 2000. Plant glycine-rich proteins: a family or just proteins with a common motif? Biochim. Biophys. Acta 1492:1-14

120. Samanani N, Liscombe DK, Facchini PJ. 2004. Molecular cloning and characterization of norcoclaurine synthase, an enzyme catalyzing the first committed step in benzylisoquinoline alkaloid biosynthesis. Plant 7. 40:302-13

121. Sarowar S, Kim YJ, Kim EN, Kim KD, Hwang BK, et al. 2005. Overexpression of a pepper basic pathogenesis-related protein 1 gene in tobacco plants enhances resistance to heavy metal and pathogen stresses. Plant Cell Rep. 24:216-24

122. Schickler H, Chet I. 1997. Heterologous chitinase gene expression to improve plant defense against phytopathogenic fungi. F. Ind. Microbiol. Biotechnol. 19:196-201

123. Schimoler-O'Rourke R, Richardson M, Selitrennikoff CP. 2001. Zeamatin inhibits trypsin and $\alpha$-amylase activities. Appl. Environ. Microbiol. 67:2365-66

124. Schlumbaum A, Mauch F, Vögeli U, Boller T. 1986. Plant chitinases are potent inhibitors of fungal growth. Nature 324:365-67

125. Schoffelmeer EAM, Klis FM, Sietsma JH, Cornelissen BJC. 1999. The cell wall of Fusarium oxysporum. Fungal Genet. Biol. 27:275-82

126. Schultheiss H, Dechert C, Király L, Fodor J, Michel K, et al. 2003. Functional assessment of the pathogenesis-related protein PR-1b in barley. Plant Sci. 165:1275-80

127. Schulze-Lefert P. 2004. Knocking on heaven's wall: pathogenesis of and resistance to biotrophic fungi at the cell wall. Curr. Opin. Plant Biol. 7:377-83

128. Seo S, Seto H, Yamakawa H, Ohashi Y. 2001. Transient accumulation of jasmonic acid during the synchronized hypersensitive cell death in Tobacco mosaic virus-infected tobacco leaves. Mol. Plant-Microbe Interact. 14:261-64

129. Serrano RL, Kuhn A, Hendricks A, Helms JB, Sinning I, et al. 2004. Structural analysis of the human Golgi-associated plant pathogenesis related protein GAPR-1 implicates dimerization as a regulatory mechanism. 7. Mol. Biol. 339:173-83

130. Shah J. 2003. The salicylic acid loop in plant defense. Curr. Opin. Plant Biol. 6:365-71

131. Shewry PR, Lucas JA. 1997. Plant proteins that confer resistance to pests and pathogens. Adv. Bot. Res. 26:135-92 
143. This paper reviews the regulation of Arabidopsis defenses through a complex network of signaling cascades involving SA, JA, ET, and the resulting differential expression of different groups of $P R$ genes.
132. Simmons CR. 1994. The physiology and molecular biology of plant $1,3-\beta$-D-glucanases and 1,3;1,4- $\beta$-D-glucanases. Crit. Rev. Plant Sci. 13:325-87

133. Slusarenko AJ, Fraser RSS, Van Loon LC. 2000. Mechanisms of Resistance to Plant Diseases. Dordrecht: Kluwer. 620 pp.

134. Spoel SH, Koornneef A, Claessens SMC, Korzelius JP, Van Pelt JA, et al. 2003. NPR1 modulates cross-talk between salicylate- and jasmonate-dependent defense pathways through a novel function in the cytosol. Plant Cell 15:760-70

135. Tabaeizadeh Z, Agharbaoui Z, Harrak H, Poysa V. 1999. Transgenic tomato plants expressing a Lycopersicon chilense chitinase gene demonstrate improved resistance to Verticillium dabliae race 2. Plant Cell Rep. 19:197-202

136. Tabei Y, Kitade S, Nishizawa Y, Kikuchi N, Kayano T, et al. 1998. Transgenic cucumber plants harboring a rice chitinase gene exhibit enhanced resistance to gray mold (Botrytis cinerea). Plant Cell Rep. 17:159-64

137. Takahashi W, Fujimori M, Miura Y, Komatsu T, Nishizawa Y, et al. 2005. Increased resistance to crown rust disease in transgenic Italian ryegrass (Lolium multiflorum Lam.) expressing the rice chitinase gene. Plant Cell Rep. 23:811-18

138. Takatsu Y, Nishizawa Y, Hibi T, Akutsu K. 1999. Transgenic chrysanthemum (Dendranthema grandiflorum (Ramat.) Kitamura) expressing a rice chitinase gene shows enhanced resistance to gray mold (Botrytis cinerea). Sci. Hortic. 82:113-23

139. Takeda S, Sato F, Ida K, Yamada Y. 1990. Characterization of polypeptides that accumulate in cultured Nicotiana tabacum cells. Plant Cell Physiol. 31:215-21

140. Takemoto D, Furuse K, Doke N, Kawakita K. 1997. Identification of chitinase and osmotin-like protein as actin-binding proteins in suspension-cultured potato cells. Plant Cell Physiol. 38:441-48

141. Tao Y, Xie Z, Chen W, Glazebrook J, Chang H-S, et al. 2003. Quantitative nature of Arabidopsis responses during compatible and incompatible interactions with the bacterial pathogen Pseudomonas syringae. Plant Cell 15:317-30

142. Thomma BPHJ, Cammue BPA, Thevissen K. 2002. Plant defensins. Planta 216:193-202

143. Thomma BPHJ, Penninckx IAMA, Broekaert WF, Cammue BPA. 2001. The complexity of disease signaling in Arabidopsis. Curr. Opin. Immunol. 13:63-68

144. Thordal-Christensen H. 2003. Fresh insights into processes of nonhost resistance. Curr. Opin. Plant Biol. 6:351-57

145. Tian M, Huitema E, Da Cunha L, Torto-Alalibo T, Kamoun S. 2004. A Kazal-like extracellular serine protease inhibitor from Phytophthora infestans targets the tomato pathogenesis-related protease P69B. F. Biol. Chem. 279:26370-77

146. Ton J, Van Pelt JA, Van Loon LC, Pieterse CMJ. 2002. Differential effectiveness of salicylate-dependent and jasmonate/ethylene-dependent induced resistance in Arabidopsis. Mol. Plant-Microbe Interact. 15:27-34

147. Trudel J, Grenier J, Potvin C, Asselin A. 1998. Several thaumatin-like proteins bind to $\beta$-1,3-glucans. Plant Physiol. 118:1431-38

148. Uknes S, Mauch-Mani B, Moyer M, Potter S, Williams S, et al. 1992. Acquired resistance in Arabidopsis. Plant Cell 4:645-56

149. Van Loon LC. 1999. Occurrence and properties of plant pathogenesis-related proteins. See Ref. 29, pp. 1-19

150. Van Loon LC. 2000. Systemic induced resistance. See Ref. 133, pp. 521-74

151. Van Loon LC, Bakker PAHM. 2006. Induced systemic resistance as a mechanism of disease suppression by rhizobacteria. In PGPR: Biocontrol and Biofertilization, ed. ZA Siddiqui, pp. 39-66. Dordrecht: Springer 
152. Van Loon LC, Gerritsen YAM, Ritter CE. 1987. Identification, purification, and characterization of pathogenesis-related proteins from virus-infected Samsun NN tobacco leaves. Plant Mol. Biol. 9:593-609

153. Van Loon LC, Pierpoint WS, Boller T, Conejero V. 1994. Recommendations for naming plant pathogenesis-related proteins. Plant Mol. Biol. Rep. 12:245-64

154. Van Loon LC, Pieterse CMJ. 2002. Biocontrol agents in signaling resistance. In Biological Control of Crop Diseases, ed. SS Gnanamanickam, pp. 355-86. New York: Marcel Dekker

155. Van Loon LC, Van Strien EA. 1999. The families of pathogenesis-related proteins, their activities, and comparative analysis of PR-1 type proteins. Physiol. Mol. Plant Pathol. 55:8597

156. Van Wees SCM, Chang H-S, Zhu T, Glazebrook J. 2003. Characterization of the early response of Arabidopsis to Alternaria brassicicola infection using expression profiling. Plant Physiol. 132:606-17

157. Van Wees SCM, De Swart EAM, Van Pelt JA, Van Loon LC, Pieterse CMJ. 2000. Enhancement of induced disease resistance by simultaneous activation of salicylate- and jasmonate-dependent defense pathways in Arabidopsis thaliana. Proc. Natl. Acad. Sci. USA 97:8711-16

158. Velazhahan R, Muthukrishnan S. 2003/4. Transgenic tobacco plants constitutively overexpressing a rice thaumatin-like protein (PR-5) show enhanced resistance to Alternaria alternata. Biol. Plant. 47:347-54

159. Verberne MC, Hoekstra J, Bol JF, Linthorst HJM. 2003. Signaling of systemic acquired resistance in tobacco depends on ethylene perception. Plant 7. 35:27-32

160. Verhagen BWM, Glazebrook J, Zhu T, Chang H-S, Van Loon LC, Pieterse CMJ. 2004. The transcriptome of rhizobacteria-induced systemic resistance in Arabidopsis. Mol. PlantMicrobe Interact. 17:895-908

161. Vernooij B, Friedrich L, Morse A, Reist R, Kolditz-Jawhar R, et al. 1994. Salicylic acid is not the translocated signal responsible for inducing systemic acquired resistance but is required in signal transduction. Plant Cell 6:959-65

162. Veronese P, Ruiz MT, Coca MA, Hernandez-Lopez A, Lee H, et al. 2003. In defense against pathogens. Both plant sentinels and foot soldiers need to know the enemy. Plant Physiol. 131:1580-90

163. Vierheilig H, Alt M, Lange J, Gut-Rella M, Wiemken A, et al. 1995. Colonization of transgenic tobacco constitutively expressing pathogenesis-related proteins by the vesiculararbuscular mycorrhizal fungus Glomus mosseae. Appl. Environ. Microbiol. 61:3031-34

164. Vijayan P, Shockey J, Lévesque CA, Cook RJ, Browse J. 1998. A role for jasmonate in pathogen defense of Arabidopsis. Proc. Natl. Acad. Sci. USA 95:7209-14

165. Vleeshouwers VGAA, Van Dooijeweert W, Govers F, Kamoun S, Colon LT. 2000. Does basal $P R$ gene expression in Solanum species contribute to non-specific resistance to Phytophthora infestans? Physiol. Mol. Plant Pathol. 57:35-42

166. Wang X, Zafian P, Choudhary M, Lawton M. 1996. The PR5K receptor protein kinase from Arabidopsis thaliana is structurally related to a family of plant defense proteins. Proc. Natl. Acad. Sci. USA 93:2598-602

167. Wang Y, Fristensky B. 2001. Transgenic canola lines expressing pea defense gene DRR206 have resistance to aggressive blackleg isolates and to Rbizoctonia solani. Mol. Breed. 8:26371

168. Wang YP, Nowak G, Culley D, Hadwiger LA, Fristensky B. 1999. Constitutive expression of pea defense gene DRR206 confers resistance to blackleg (Leptosphaeria maculans) disease in transgenic canola (Brassica napus). Mol. Plant-Microbe Interact. 12:410-18
153. The original paper defining PRs and their classification into families, with special emphasis on tobacco and tomato. 
169. Ward ER, Uknes SJ, Williams SC, Dincher SS, Wiederhold DL, et al. 1991. Coordinate gene activity in response to agents that induce systemic acquired resistance. Plant Cell 3:1085-94

170. Worrall D, Hird DL, Hodge R, Paul W, Draper J, Scott R. 1992. Premature dissolution of the microsporocyte callose wall causes male sterility in transgenic tobacco. Plant Cell 4:759-71

171. Wróbel-Kwiatkowska M, Lorenc-Kukula K, Starzycki M, Oszmiański J, Kepczyńska E, et al. 2004. Expression of $\beta$-1,3-glucanase in flax causes increased resistance to fungi. Physiol. Mol. Plant Pathol. 65:245-56

172. Wu C-T, Leubner-Metzger G, Meins F, Bradford KJ. 2001. Class I $\beta$-1,3-glucanase and chitinase are expressed in the micropylar endosperm of tomato seeds prior to radicle emergence. Plant Physiol. 126:1299-313

173. Yagami T. 2000. Defense-related proteins as families of cross-reactive plant allergens. Recent Res. Dev. Allergy Clin. Immunol. 1:41-64

174. Yagami T, Sato M, Nakamura A, Komiyama T, Kitagawa K, et al. 1998. Plant defenserelated enzymes as latex antigens. F. Allergy Clin. Immunol. 101:379-85

175. Yamamoto T, Iketani H, Ieki H, Nishizawa Y, Notsuka K, et al. 2000. Transgenic grapevine plants expressing a rice chitinase with enhanced resistance to fungal pathogens. Plant Cell Rep. 19:639-46

176. Yoneyama K. 1998. Novel approaches to disease control. In Fungicidal Activity, ed. DH Hutson, J Miyamoto, pp. 221-45. New York: Wiley

177. Yoshikawa M, Tsuda M, Takeuchi Y. 1993. Resistance to fungal diseases in transgenic tobacco plants expressing the phytoalexin elicitor-releasing factor, $\beta$-1,3-endoglucanase, from soybean. Naturwissenschaften 80:417-20

178. Yu X-M, Griffith M, Wiseman SB. 2001. Ethylene induces antifreeze activity in winter rye leaves. Plant Physiol. 126:1232-40

179. Yun D-J, Bressan RA, Hasegawa PM. 1997. Plant antifungal proteins. In Plant Breeding Reviews, ed. J Janick, pp. 39-80. New York: Wiley

180. Yun D-J, Zhao Y, Pardo JM, Narasimhan ML, Damsz B, et al. 1997. Stress proteins on the yeast cell surface determine resistance to osmotin, a plant antifungal protein. Proc. Natl. Acad. Sci. USA 94:7082-87

181. Zhu B, Chen THH, Li PH. 1993. Expression of an ABA-responsive osmotin-like gene during the induction of freezing tolerance in Solanum commersonii. Plant Mol. Biol. 21:729_ 35

182. Zimmerli L, Stein M, Lipka V, Schulze-Lefert P, Somerville S. 2004. Host and non-host pathogens elicit different jasmonate/ethylene responses in Arabidopsis. Plant 7. 40:633-46

183. Zimmermann P, Hirsch-Hoffmann M, Hennig L, Gruissem W. 2004. GENEVESTIGATOR. Arabidopsis microarray database and analysis toolbox. Plant Physiol. 136:262132 
R

Contents

Annual Review of Phytopathology

Volume 44, 2006

A Retrospective of an Unconventionally Trained Plant Pathologist:

Plant Diseases to Molecular Plant Pathology

Seiji Ouchi

The Current and Future Dynamics of Disease in Plant Communities

Feremy 7. Burdon, Peter H. Thrall, and Lars Ericson

A Catalogue of the Effector Secretome of Plant Pathogenic Oomycetes

Sophien Kamoun

Genome Packaging by Spherical Plant RNA Viruses

A.L.N. Rao

Quantification and Modeling of Crop Losses: A Review of Purposes

Serge Savary, Paul S. Teng, Laetitia Willocquet, and Forrest W. Nutter, fr.

Nonsystemic Bunt Fungi-Tilletia indica and T. horrida: A Review of

History, Systematics, and Biology

Lori M. Carris, Lisa A. Castlebury, and Blair 7. Goates

Significance of Inducible Defense-related Proteins in Infected Plants

L.C. van Loon, M. Rep, and C.M.F. Pieterse

Coexistence of Related Pathogen Species on Arable Crops in Space and Time

Bruce D. L. Fitt, Yong-Hu Huang, Frank van den Bosch, and fonathan S. West

Virus-Vector Interactions Mediating Nonpersistent and Semipersistent

Transmission of Plant Viruses

Fames C.K. Ng and Bryce W. Falk

Breeding for Disease Resistance in the Major Cool-Season Turfgrasses

Stacy A. Bonos, Bruce B. Clarke, and William A. Meyer

Molecular Ecology and Emergence of Tropical Plant Viruses

D. Fargette, G. Konaté, C. Fauquet, E. Muller, M. Peterschmitt, and F.M. Thresh ... 235

Biology of Flower-Infecting Fungi

Henry K. Ngugi and Harald Scherm 
A Model Plant Pathogen from the Kingdom Animalia: Heterodera glycines, the Soybean Cyst Nematode

T.L. Niblack, K.N. Lambert, and G.L. Tylka

Comparative Genomics Reveals What Makes an Enterobacterial Plant

Pathogen

Ian K. Toth, Leighton Pritchard, and Paul R.F. Birch

The Dawn of Fungal Pathogen Genomics

Fin-Rong Xu, You-Liang Peng, Martin B. Dickman, and Amir Sharon

Fitness of Human Enteric Pathogens on Plants and Implications for

Food Safety

Maria T. Brandl

The Role of Ethylene in Host-Pathogen Interactions

Willem F. Broekaert, Stijn L. Delauré, Miguel F.C. De Bolle, and Bruno P.A. Cammue

Phenazine Compounds in Fluorescent Pseudomonas Spp. Biosynthesis and Regulation

Dmitri V. Mavrodi, Wulf Blankenfeldt, and Linda S. Thomashow

Long-Distance RNA-RNA Interactions in Plant Virus Gene

Expression and Replication

W. Allen Miller and K. Andrew White

Evolution of Plant Pathogenicity in Streptomyces

Rosemary Loria, Johan Kers, and Madbumita Foshi

Climate Change Effects on Plant Disease: Genomes to Ecosystems

K.A. Garrett, S.P. Dendy, E.E. Frank, M.N. Rouse, and S.E. Travers

\section{INDEX}

Subject Index

\section{ERRATA}

An online log of corrections to Annual Review of Phytopathology chapters (if any, 1977 to the present) may be found at http://phyto.annualreviews.org/ 